\title{
Disaster Risk Reduction and Building Resilience in the Hindu Kush Himalaya
}

\section{Coordinating Lead Authors}

Ramesh Ananda Vaidya, International Centre for Integrated Mountain Development (ICIMOD), e-mail: Ramesh.Vaidya@icimod.org

Mandira Singh Shrestha, International Centre for Integrated Mountain Development (ICIMOD), e-mail: Mandira.Shrestha@icimod.org (corresponding author)

Nusrat Nasab, Aga Khan Agency for Habitat (AKAH), e-mail: nusrat.nasab@akdn.org

\section{Lead Authors}

Deo Raj Gurung, Aga Khan Agency for Habitat (AKAH), e-mail: deoraj.gurung@akdn.org Nagami Kozo, Japan International Cooperation Agency (JICA), e-mail: Nagami.Kozo@jica.go.jp Neera Shrestha Pradhan, International Centre for Integrated Mountain Development (ICIMOD), e-mail: Neera.Pradhan@icimod.org

Robert James Wasson, National University of Singapore, e-mail: spprjw@nus.edu.sg

\section{Contributing Authors}

Arun Bhakta Shrestha, International Centre for Integrated Mountain Development (ICIMOD), e-mail: arun.shrestha@icimod.org

Chanda Goodrich Gurung, International Centre for Integrated Mountain Development (ICIMOD), e-mail: Chanda.Goodrich@icimod.org

Ajay Bajracharya, University of Manitoba, Winnipeg, Canada, e-mail: ajay6985@yahoo.com

\section{Review Editor}

Purnamita Dasgupta, Institute of Economic Growth, India, e-mail: pdg@iegindia.org

\section{Corresponding Author}

Mandira Singh Shrestha, International Centre for Integrated Mountain Development (ICIMOD), e-mail: Mandira.Shrestha@icimod.org 


\section{Contents}

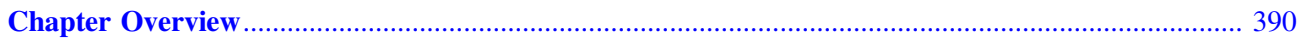

11.1 The Hindu Kush Himalaya: An Uncertain, Multi-hazard Environment ................................. 393

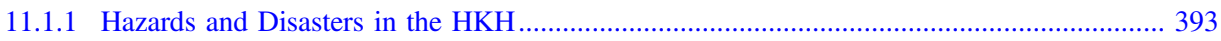

11.1.2 Disaster Trends in the HKH .................................................................................... 398

11.1.3 Linking Primary and Secondary Hazards - The Mountain Perspective.............................. 399

11.2 Vulnerability: Physical, Social, Economic, and Environmental Dimensions ........................... 401

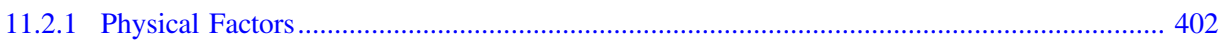

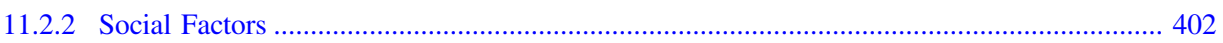

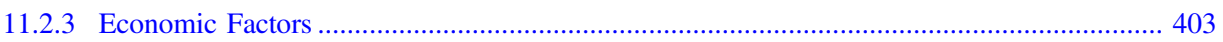

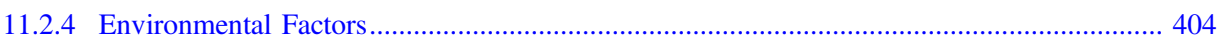

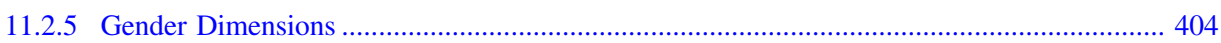

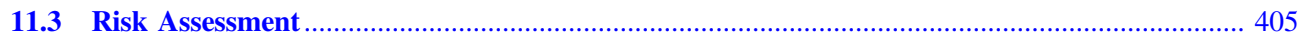

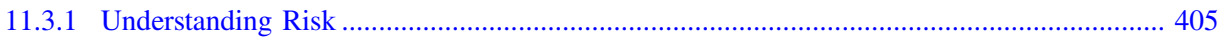

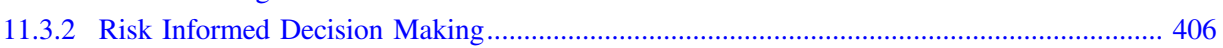

11.4 A Framework for Policies to Reduce Risk and Enhance Resilience .......................................... 407

11.4.1 A Framework for Reducing Risk and Increasing Resilience to Disasters ........................... 407

11.4.2 Relating the Disaster Risk Reduction Elements to Programme Components ...................... 409

11.4.3 Resilience Building Programmes: Four Examples ......................................................... 409

11.4.4 Information Flows Are Crucial for Early Warning Systems.................................................. 411

11.4.5 Building Critical Infrastructure Which Is Resilient to Disasters............................................ 412

11.4.6 The Role of Institutions Is Critical in Resilience Building Measures ................................. 413

11.4.7 Nudging Could Help Motivate People for Self-insurance ................................................ 413

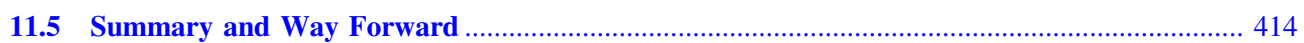

References

\section{Chapter Overview}

\section{Key Findings}

1. More than one billion people are at risk of exposure to increasing frequency and intensity of natural hazards. Rising trends appear in the number of disasters reported, the numbers of people killed and affected, and the size of economic losses. This is due to various drivers including climatic change and environmental degradation.

2. Cascading events resulting from a multi-hazard environment have upstream-downstream linkages, often with transboundary impacts. The HKH is especially prone to floods, flash floods, avalanches, and landslides, but also to droughts and earthquakes. The number of GLOFs in the region are increasing. There is lack of institutional mechanism and capacity to deal with multi-hazard environment and cascading disasters.
3. When disasters hit the HKH, they affect more women than men. Gender is one of the most significant factors affecting vulnerability to disasters in the region. This can be ascribed to women's lack of access to information, power, money, and training, high rates of male outmigration, and associated gender-based norms and barriers.

\section{Policy Messages}

1. Institutions and governments in the HKH urgently need to adopt a standardized, multi-hazard risk assessment approach. Such an approach should address primary, secondary, and cascading hazards. 
2. All stakeholders including governments, individuals, households, and communities need to take urgent action for enhancing resilience through the four pillars-information, infrastructure, institutions, and insurance. A balanced use of four key instruments is required: command and control, monetary incentives, persuasion, and nudging. Sensitization to gender differential vulnerabilities within society must be inculcated for reducing mortality and morbidity.

3. The countries of the HKH need to cooperate more extensively and effectively by sharing data, information, and scientific and indigenous knowledge, and by fostering transboundary disaster risk reduction practices. Institutional arrangements for collective action should be enhanced and capacity building programmes organized for strengthening regional cooperation.

The Hindu Kush Himalaya ( $\mathrm{HKH}$ )— covering more than four million square kilometres from Afghanistan to Myanmar-is one of the world's most ecologically diverse mountain biomes, with extreme variations in vegetation. It is also one of the most hazard-prone. Because of its steep terrain, high seismicity, fragile geological formation, and intense and highly variable precipitation, the HKH is especially vulnerable to floods, landslides, avalanches, and earthquakes (well-established).

Currently, natural hazards in the HKH are increasing in magnitude and frequency - a trend driven partly by climate change. Environmental degradation generally poses a major threat to lives and livelihoods. However, a community's vulnerability to natural hazards also includes the exposure of people and property to disasters and their impact.

While some of the factors in exposure and vulnerability are physical and environmental, other factors are socioeconomic, such as poverty, human settlement and habitat, lack of preparedness, susceptibility, and adaptive capacity. Poverty leaves many people in the region with few resources when trying to rebuild their homes and livelihoods (see Chap. 12). With the exception of China, the countries of the HKH rank below the global average on the Human Development Index (HDI). Income inequality is also high throughout the region, except in China and Bangladesh. These facts imply high vulnerability to natural hazards (well-established).

Gender emerges as one of the most significant socioeconomic factors affecting vulnerability. While both men and women in the HKH have valuable knowledge, skills, experience, and coping capacities, these strengths tend to differ by gender (see Chap. 14). And unlike men's capacities and knowledge, those of women are often ignored in policies and formal arrangements related to development, mitigation and recovery. As we stress in the chapter, policy makers and planners must ensure that women actively participate in capacity building and gain access to information that would prepare them better for disasters. Indicators related to both gender equality and education are even more dramatically low for the HKH compared with world averages, than are income and income equality (well-established).

Disaster risks are a function of interplay between three key elements: hazard, exposure, and vulnerability. Natural hazards are increasing in magnitude and occurrence due to various drivers of change including climate change. The susceptibility of a community to the impact of a natural hazard increases due to both exposure of people and property to the hazard, and vulnerability. The IPCC AR5 also elaborates on the interactions among these key elements in addressing the need for risk management and adaptation to the risks of climate change. Based on this concept of disaster risk, hazard, exposure, and vulnerability, this chapter envisions a policy framework to reduce risk and enhance resilience. When seeking ways to increase resilience to disasters in the HKH, policy makers need to consider five key issues:

1. the multi-hazard environment,

2. close links between upstream and downstream hazards,

3. the effects of climate change and variability,

4. the challenge of connectivity and physical access, and

5. governance.

The multi-hazard environment is common to many countries of the HKH (well-established). In Nepal, for example, the local term for floods is badhi-pahiro, 'floods and landslides'-probably because of the way in which flooding mountain streams can erode river banks by undercutting, leading to landslides which in turn can form natural dams that later breach, causing flash floods. Similarly, earthquakes can trigger both landslides and flash floods. Efforts to build resilience thus need to consider not just the primary event, but also secondary hazards involving cascading threats and disasters (Shrestha et al. 2016).

Also important are the upstream and downstream linkages of hazard events. Exposure to hazards can extend, though with a time lag, to an area much larger than the site of the primary event, often across international borders. Even within the same country, physical infrastructure that is supposed to increase resilience, such as early warning systems for flash floods, may not be as widely available as necessary. Institutional arrangements for coordination and cooperation at various levels could also be an issue when managing linkages between upstream and downstream hazard events, especially if the communities at each end lack mechanisms for reciprocal cooperation, and this is compounded when the 
affected areas lie across international boundaries. For example, the outburst of a landslide-dammed lake in the Tibetan Autonomous Region of China could seriously damage a Nepalese hydropower plant. Similarly, events in Nepal could endanger India's densely populated northern states. Communication channels between local authorities in upstream and downstream nations are often poorly developed and central government efforts to establish communication may intervene too late to save human lives or infrastructure (established but incomplete).

Among the impacts of climate change and variability are the growing number and size of glacial lakes: Himalayan glaciers have retreated rapidly in recent decades, causing many such lakes to form and expand (see Chap. 7) (wellestablished). Climate change is expected to lead to further increases (established but incomplete). The instability of the moraine materials holding back these lakes poses a risk of glacial lake outburst floods (GLOF). In addition, shifting monsoon patterns may result in episodes of intense precipitation, leading to further increases in floods, landslides, and soil erosion (established but incomplete).

The challenge of connectivity and physical access can involve road and air travel and information and communications technology in sparsely-settled and often remote mountain areas. Finally, this very remoteness raises governance as a key issue. Compared to better connected areas, local governments and communities need the capacity to make decisions about hazards that commonly affect isolated and remote locations. In addition, national plans and institutional options for strengthening adaptive capacity may not fully reflect local realities and could be more thoroughly informed by local adaptation concerns (inconclusive).

To address these five key issues for upstream and downstream communities in the $\mathrm{HKH}$, we present a new disaster risk reduction (DRR) framework that can help in assessing hazard and risks while discussing adaptation and resilience measures. While developed specifically for the region, it draws on two existing frameworks: the Hyogo Framework for Action 2005-15 and the Sendai Framework for Disaster Risk Reduction 2015-2030. It has four elements:

- Information: sharing hazard information between upstream and downstream communities, ensuring communication about cascading hazards

- Infrastructure: adapting to climatic and seismic risks, investing to enhance connectivity

- Institutions: addressing gender and governance dimensions and developing mechanisms to connect national institutions, policies, and actions with local ones

- Insurance: insuring, or transferring risk, to build resilience to residual disaster risks (those that may not be eliminated)
We also present a matrix showing how these four disaster risk reduction elements can interact with four components of resilience-building programmes:

1. command-and-control mechanisms such as zoning regulations, land use guidelines, and building codes;

2. monetary incentives such as subsidies on insurance premiums;

3. persuasive information such as risk maps; and

4. 'nudges' such as early warning systems.

Alongside the new disaster risk reduction framework, standard multi-hazard risk assessment protocols are needed to study the HKH as a multi-hazard environment. Cascading hazards, especially, require a multi-hazard methodology that integrates complex "hazard interactions and interaction networks" and a multi-hazard early warning system. Successful management critically depends on such assessments-but tools for the HKH have not yet been developed. The process of creating these standard protocols must be as participatory as possible, comprised of diverse stakeholder perspectives.

Because natural hazards know no borders, disaster risk reduction in the $\mathrm{HKH}$ would benefit greatly from stronger regional cooperation [established but incomplete]. Events such as the 2005 Kashmir earthquake and the 2010 Pakistan floods have prompted calls for increased efforts. In the Asia regional plan for implementation of the Sendai framework for disaster risk reduction 2015-2030 a two-year action plan for 2017 to 2018 seeks to strengthen existing regional mechanisms to reduce the risk of, and enhance early warning and preparedness for, transboundary disasters. A regional approach, with efforts in timely data sharing and modelling, should improve flood management and help mitigate adverse impacts in transboundary basins.

Disaster Risk Reduction (DRR), the HKH, and the Sustainable Development Goals (SDGs)

Building disaster resilience in the mountains requires decision making that is informed by the best available studies of disaster risk reduction (DRR) and climate change adaptation. Because of mountain communities' high vulnerability to extreme weather events and natural hazards such as floods, landslides, earthquakes, and avalanches, disaster risk reduction assumes a high profile in the 2030 sustainable development agenda. Especially relevant to the HKH are Sustainable Development Goals (SDGs) 1 (End poverty), 5 (Gender equality and empowerment of women and girls), 9 (Build resilient infrastructure), 11(Make cities and human settlements inclusive, safe, resilient and sustainable), 13 (Combat climate change), and 15 
(Manage forests and combat desertification).To complement the relevant formal SDGs, we propose the following vision for mountain disaster risk reduction: By 2030, build resilience to reduce disaster risks and losses in lives, livelihoods and assets from natural disasters in mountain regions substantially through informed decision making and enhanced preparedness. Supporting this vision are four targets:

1. Reduce human deaths, economic loss, and the number of people affected due to disasters and extreme climate events, especially for women and children [SDGs 5, 13].

2. Make human settlements and habitats safe, inclusive, resilient, and sustainable through capacity building, legislation, education, livelihoods, better zoning and building regulations, and a multi-hazard risk reduction approach [SDGs 9, 11, 13].

3. Ensure protection from exposure to extreme events such as floods and droughts [SDGs 1, 13].

4. Provide access to disaster risk reduction and mitigation measures, including finance and technology, with the knowledge and capacity building needed to use them [SDG 13].

\subsection{The Hindu Kush Himalaya: An Uncertain, Multi-hazard Environment}

Disaster risk depends on how likely different kinds and intensities of natural hazards are to occur, the elements exposed, and their vulnerability (World Bank 2005). Mountain development and disaster risk are inherently linked, as many mountain settlements are located on unstable mountain slopes that are prone to landslide and erosion, or on river terraces and alluvial fans that are susceptible to debris flows and floods. The Hindu Kush Himalaya (HKH) is one of the most fragile mountain regions in the world. Because of its unique geology, steep terrain, intense seasonal precipitation, and high seismicity, the region is highly vulnerable to floods (especially flash floods), landslides, droughts, and earthquakes - a truly multi-hazard environment.

\subsubsection{Hazards and Disasters in the HKH}

Across the world, the number of extreme geophysical and hydrometeorological events appears to be increasing, resulting in a growing loss of lives and increasing damage to livelihood support systems. The HKH accounted for $21 \%$ (4,115 of $18,956)$ of the major disaster events recorded between 1980 and 2015 in the Em-DAT global database, and 36\% of the major events in Asia. Floods and landslides are the most frequently occurring natural hazards, particularly during the monsoon season (Shrestha 2008a, b; Gaire et al. 2015); they accounted for nearly half of the events recorded in the countries of the HKH region (Fig. 11.1).

The number of disaster events from climate, hydrometeorological and geophysical hazards recorded in the countries of the HKH region between 1980 and 2015 is shown in Fig. 11.2. A total of 739 disaster events were recorded in China, 438 in India, and 229 in Bangladesh. Floods are prominent across all countries, landslides in inland countries (Afghanistan, Nepal, and Pakistan), and storms in coastal countries (China, India, and Myanmar). Wildfires are also on the rise across the region.

In a mortality ranking conducted by ADB (2013b), seven of the eight countries in the HKH were included in the 20 Asian countries (out of 44) rated as mortality hotspots (Table 11.1).

Floods and flash floods: Floods, both riverine and flash floods, are the most common hazards in the HKH (Shrestha et al. 2015) and account for $17 \%$ of people killed and $51 \%$ of the damage (Fig. 11.1). Unlike riverine floods, flash floods occur rapidly with a very short lead time for warning. They can arise following intense rainfall events, or as a result of breaching of natural dams formed by landslides or from glacial lakes formed behind end moraine dams (glacial lake outburst flood or GLOF) (Shrestha 2008a, b). In recent years, increasingly erratic and unpredictable monsoon rainfall patterns and increased climate variability have led to severe and frequent flood disasters in the region. This has adversely impacted lives and livelihoods, agricultural productivity, and hydropower production, among others. For example, the 2010 floods in Pakistan killed more than 2,000 people, with an estimated loss of USD 10 billion (FFC 2010). In India, the 2013 flood in Uttarakhand killed more than 5,000 people (Awasthi et al. 2014; Guha-Sapir et al. 2014; Champati Ray et al. 2016), and possibly as many as 30,000 (Ziegler et al. 2014). Bangladesh is one of the countries in the region most vulnerable to floods, as it is situated on the delta of three major HKH river systems: the Ganges, Brahmaputra, and Meghna (Islam et al. 2010). In Pakistan, flooding is the most frequently occurring hazard; it affects thousands of people and causes millions of dollars of damage annually (Tariq and Giesen 2011). Table 11.2 shows the large flood events reported in the HKH from 1980 to 2015. Figure 11.3 shows the spatial extent and impact of flood disasters occurring between 2010 and 2014. 


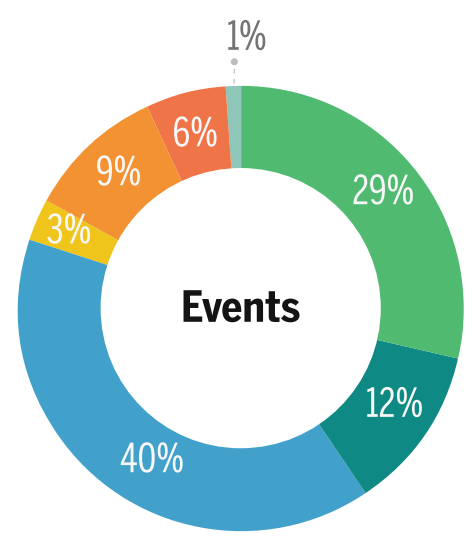

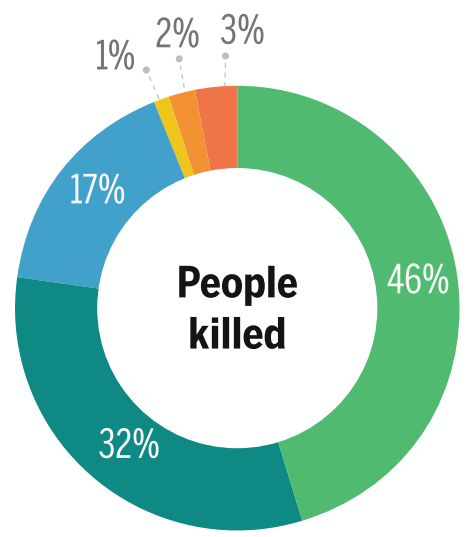
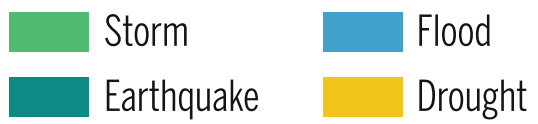
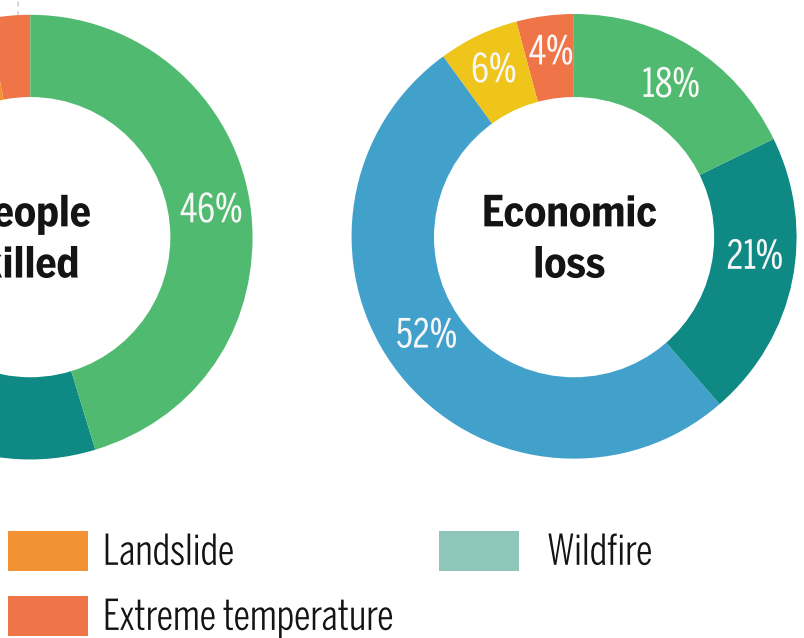

Fig. 11.1 Proportional impact of different types of disaster in HKH countries (whole country, including HKH area) between 1980 and $2015-$ number of events, persons killed, and economic loss (Source EM-DAT: The Emergency Events Database-Université catholique de Louvain (UCL) - CRED, D. Guha-Sapir-www.emdat.be, Brussels, Belgium)

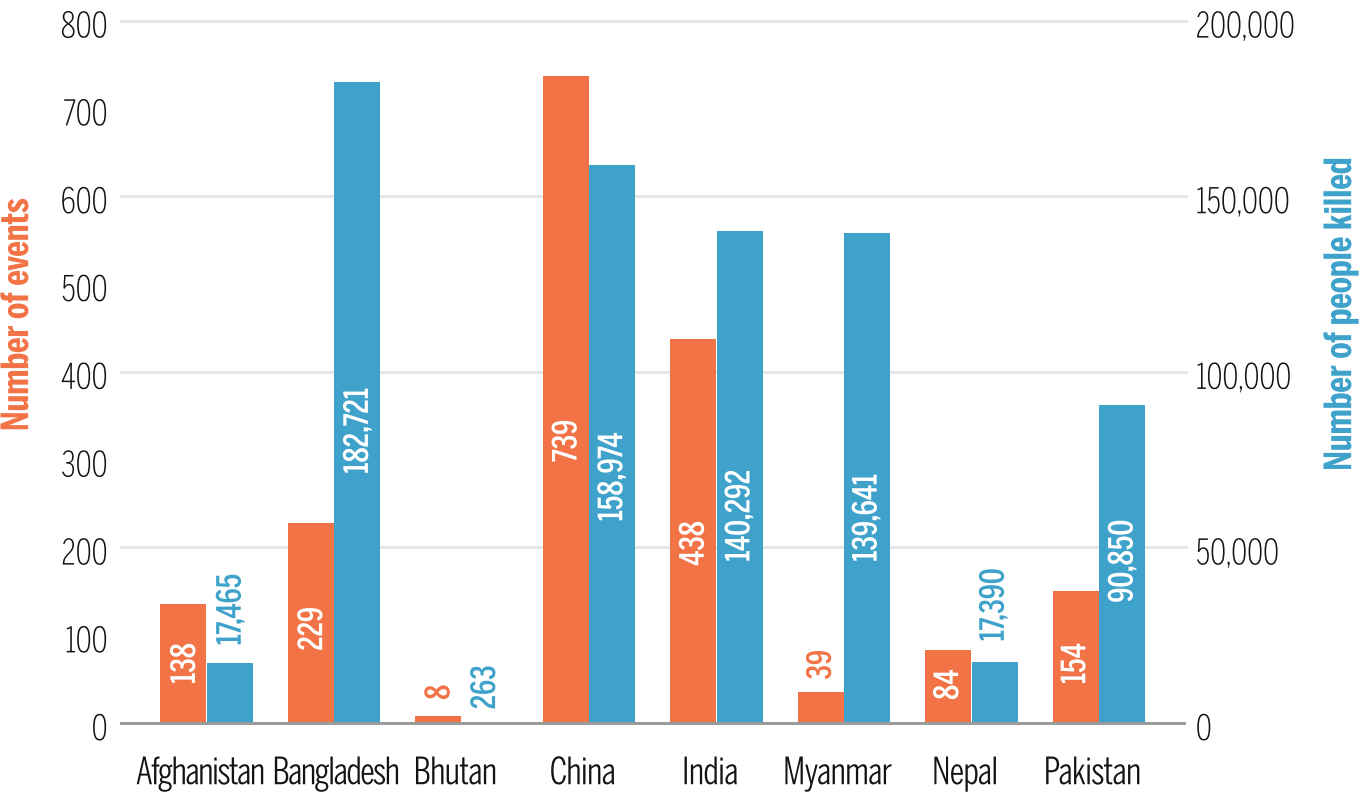

Fig. 11.2 Disaster number (a) and people killed (b) by climate, hydrometeorological, and geophysical disaster events in $\mathrm{HKH}$ countries (whole country, including HKH area) between 1980 and 2015

As of 2000, the HKH has witnessed more than 33 identifiable GLOFs (Richardson and Reynolds 2000). Accelerated glacial thinning, degraded permafrost (Haeberli et al. 2016), and additional retreat in response to rising global temperatures are expected to increase GLOF events in the future (Ives et al. 2010). The most recent recorded GLOFs occurred at Lemthang Tsho in western Bhutan in June 2015 (Gurung et al. 2017) and in multiple locations in Chitral,
(Source EM-DAT: The Emergency Events Database-Université catholique de Louvain (UCL) - CRED, D. Guha-Sapir-www.emdat. be, Brussels, Belgium)

Pakistan in July 2016. A GLOF upstream of Uttarakhand in 2013 (Allen et al. 2015; Champati Ray et al. 2016) damaged high value infrastructure like hydropower dams (Schwanghart et al. 2016) and impacted the lives of more than 100,000 people. Ice avalanches into expanding lakes can also lead to GLOFs and cause large floods downstream (Haeberli et al. 2016). The number of GLOFs in the HKH is increasing (see Box 11.1). 
Table 11.1 High mortality risks from multiple hazards in the HKH

\begin{tabular}{l|l|l|l|l}
\hline $\begin{array}{l}\text { Mortality } \\
\text { ranking }\end{array}$ & $\begin{array}{l}\text { Ranked HKH } \\
\text { countries }\end{array}$ & $\begin{array}{l}\text { Percent of population } \\
\text { in areas at risk }\end{array}$ & $\begin{array}{l}\text { Estimated number of } \\
\text { people at risk (millions) }\end{array}$ & $\begin{array}{l}\text { Percent of total } \\
\text { area at risk }\end{array}$ \\
\hline 1 & Bangladesh & 97.7 & 139.6 & 97.1 \\
\hline 2 & Nepal & 97.4 & 25.9 & 80.2 \\
\hline 5 & Bhutan & 60.8 & 0.4 & 31.2 \\
\hline 7 & Pakistan & 49.6 & 87.84 & 22.8 \\
\hline 8 & Afghanistan & 46.0 & 12.2 & 7.2 \\
\hline 11 & China & 33.4 & 450.0 & 10.6 \\
\hline 14 & India & 27.2 & 337.8 & 21.9 \\
\hline 16 & Myanmar & 16.8 & 10.1 & 4.5 \\
\hline
\end{tabular}

Source ADB (2013b)

Table 11.2 Severe floods between 1980 and 2015 in the countries of the $\mathrm{HKH}$ region

\begin{tabular}{l|l|l|l|l}
\hline Country & Year & Month & People killed & People affected \\
\hline India & 2013 & June & 6,453 & $3,419,473$ \\
\hline Pakistan & 2010 & July & 2,113 & $20,363,496$ \\
\hline Bangladesh & 2007 & September & 1,230 & $13,851,440$ \\
\hline India & 1998 & July & 2,131 & $29,652,200$ \\
\hline Bangladesh & 1998 & September & 1,050 & $15,000,050$ \\
\hline India & 1997 & September & 2,357 & $30,259,020$ \\
\hline Nepal & 1993 & July & 1,048 & 553,268 \\
\hline Pakistan & 1992 & September & 1,446 & $12,839,868$ \\
\hline Afghanistan & 1991 & May & 1,193 & 139,400
\end{tabular}

Source EM-DAT: The Emergency Events Database-Université catholique de Louvain (UCL) - CRED, D. Guha-Sapir-www.emdat.be, Brussels, Belgium

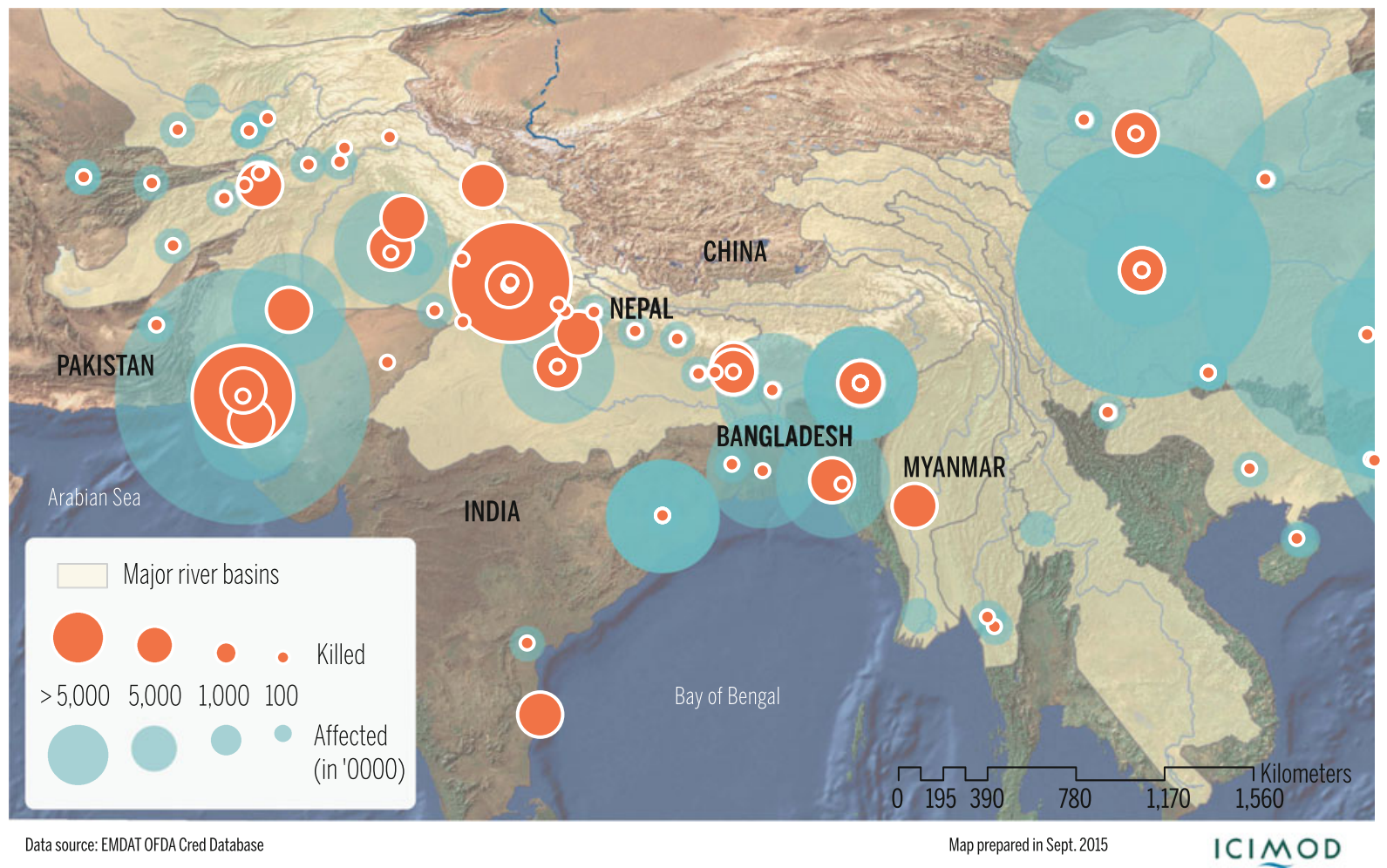

Fig. 11.3 Spatial extent and impact of flood disasters in the major river basins originating in HKH from 2010 to 2014 (Source EM-DAT: The Emergency Events Database-Université catholique de Louvain (UCL) - CRED, D. Guha-Sapir—www.emdat.be, Brussels, Belgium) 


\section{Box 11.1 Upper Indus glacial lake outburst floods (GLOFs), 1826-2000 CE}

Glacial lake outburst floods (GLOFs) can cause considerable damage to life and property. Reviewing 174 years of data from the Karakoram region, Hewitt and Liu (2010) noted that GLOF events have become more frequent in the upper Indus catchment (see Fig. 11.4). Comparison of tree-ring-based precipitation (Singh et al. 2006) and temperature records (Yadav and Singh 2002) in the high western Himalaya, suggests that during period A (1826-1893) temperatures were low and precipitation was decreasing, during period B (1893-1934) temperatures were even lower and precipitation still decreasing, whereas during period C (1934-2000) temperatures were rising and precipitation increasing. The highest frequency of GLOFs occurred when temperatures were at their lowest, particularly in the first part of period B. The climatic controls on the glaciers and these floods are not clear, but there is no evidence of a recent increase of GLOFs that may be attributed to global warming.

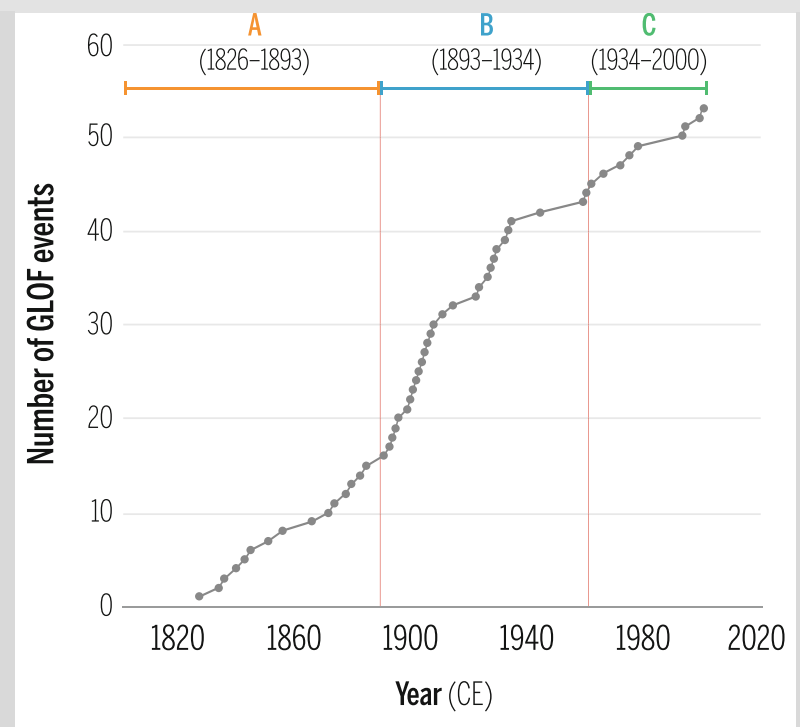

Fig. 11.4 Increasing frequencies of GLOF events in the Upper Indus (Data source Hewitt and Liu 2010)

Global flood projections based on the Multiple Coupled Model Intercomparison Project, Version 5-Global Climate Model (CMIP5-GCM) simulations coupled with global hydrology and land surface models show flood hazards increasing over approximately half of the globe, but with great variability at the catchment scale (Dankers et al. 2014). The projected increases in temperature and intense precipitation will induce regional-scale changes in flood frequency and intensity (IPCC 2012), resulting in changes in extreme weather patterns (Elalem and Pal 2015). The Arctic Oscillation and its interaction with the monsoon will also play a role in climate change in the HKH (Joseph et al. 2013); as the Arctic grows warmer, outbursts of cold and dry air are likely to increase, producing more frequent and intense rainfall and triggering increased flooding. Climate change and the accompanying increase in rainfall intensity and alteration of the hydrological cycle have reportedly increased the likelihood of landslides and flooding in $\mathrm{HKH}$ countries such as Bhutan and Nepal (Khanal et al. 2007).

Landslides: The HKH is characterized by steep topography: more than $40 \%$ of the land area has a slope of $15^{\circ}$ or more (Fig. 11.5). With fragile geological formations, a seismically active mountain system, and intense precipitation, the region is a global hot spot for landslides. Hydroclimatic and seismic sensitivity in the area increases the hazard level (Fig. 11.6). Anthropogenic influences like unsustainable development and excessive resource extraction-particularly deforestation and road building-have adversely influenced slope stability and aggravated the possibility of landslide.

Landslides are also common, with the HKH countries accounting for $52 \%$ of the landslide events and $61 \%$ of deaths recorded in Asia in the Em-DAT global database over the period 1980 to 2015 . Global disaster databases tend to grossly underestimate landslide fatalities as these are normally recorded under the primary trigger and not the hazard itself (Nadim et al. 2006). Nevertheless, landslides still

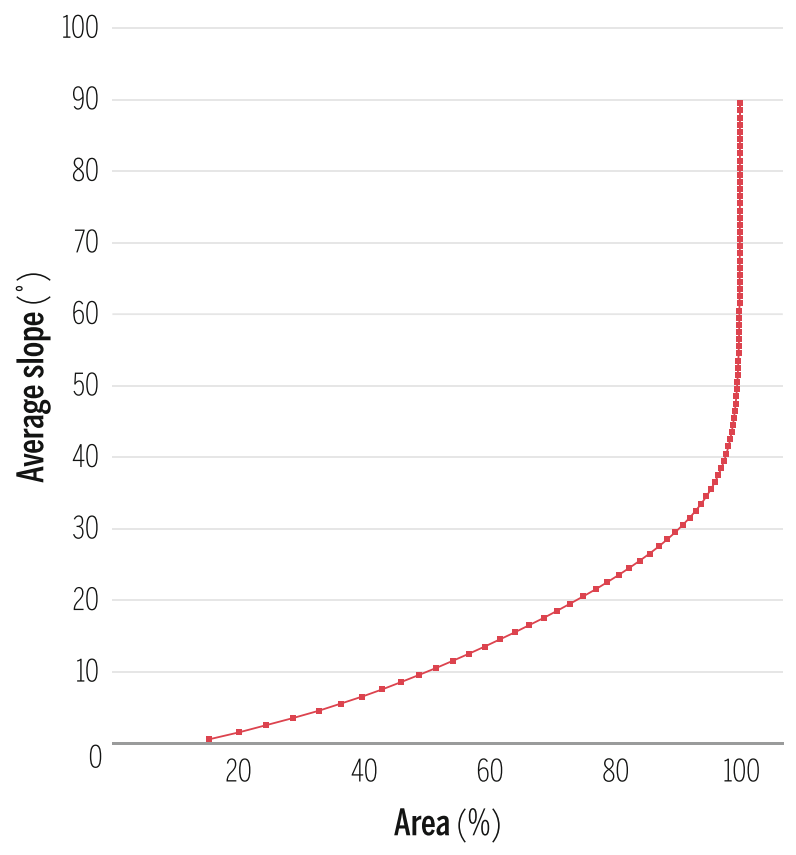

Fig. 11.5 Area characterization of the HKH (Source Developed for this chapter by Deo Raj Gurung, using $90 \mathrm{~m}$ Shuttle Radar Topographic Mission (SRTM) DEM, available at http://srtm.csi.cgiar.org/) 
Fig. 11.6 Landslide hazard a induced by precipitation, b induced by earthquakes

(Source Nadim et al. 2013) (a) Precipitation-induced landslide hazard

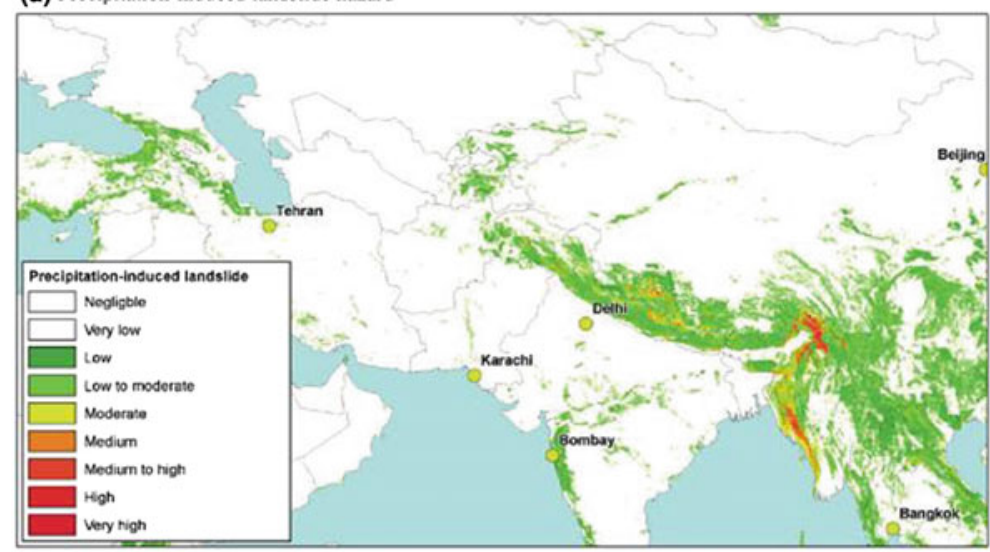

(b) Earthquake-induced landslide hazard

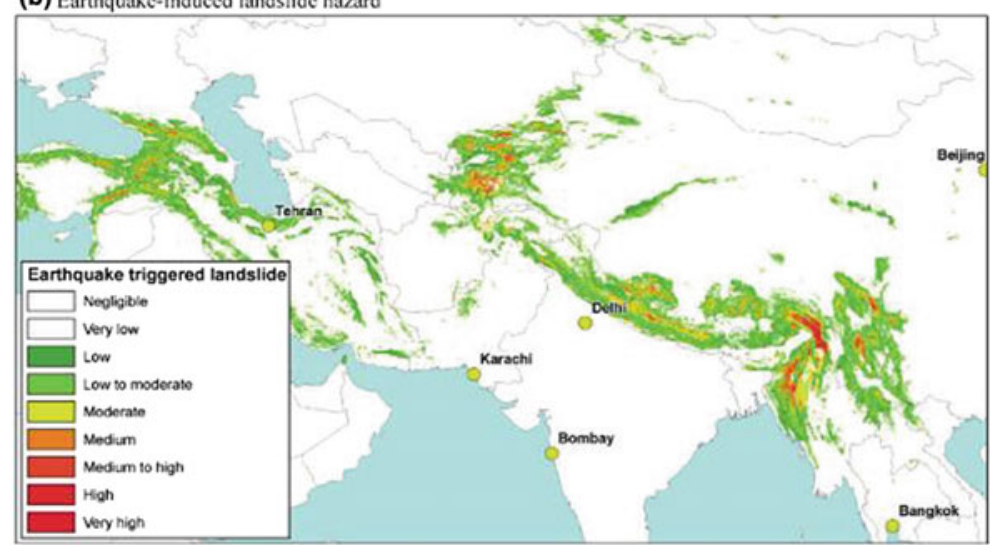

register as among the most catastrophic disasters in the HKH region (Upreti and Dhital 1996; Sarwar 2008; MoSWRR 2009; SAARC 2010; Khan and Khan 2015; Lotay 2015) (Fig. 11.6). Projections give even more cause for concern: a simple analysis using global population density data and a digital elevation model to estimate the number of people in the $\mathrm{HKH}$ living on land with a slope of $10-50^{\circ}$ shows approximately 5.2 million people at risk of exposure to landslides.

Avalanches: Avalanches are one of the biggest hazards in mountainous terrain where geographic and meteorological conditions give rise to heavy precipitation and accumulations of snow and ice that can hurtle down into inhabited valleys. Avalanches are common in the mountainous areas of the HKH region in winter. Loss of life and property is observed annually in the higher snow-covered areas of Afghanistan, Bhutan, India, Nepal, and Pakistan (SDMC 2008) (see Box 11.2). The 2015 Nepal earthquake triggered several avalanches which killed more than twenty people. In 2014, the Hudhud cyclone initiated in the Bay of Bengal brought heavy precipitation to Nepal resulting in avalanches that killed more than 43 people (Wang et al. 2015).

\section{Box 11.2 Avalanches in Afghanistan}

Two million people in Afghanistan are exposed to avalanches, and between 2000 and 2015, more than 153,000 people were affected (World Bank 2017). Heavy snowfall in Panjshir Province in February 2015 triggered 40 avalanches that killed at least 124 people, and in February 2017 avalanches near the Pakistan border killed at least 137 people.

Earthquakes: The HKH is one of the world's youngest mountain belts (GFDRR 2012) and is tectonically active. The major cause of earthquakes in the Himalaya is the subduction of the Indian plate underneath the Eurasian plate, which causes contraction and stress concentration. Seismicity is considered high in this region based on the frequency and intensity of past earthquakes (Rai 2004). Plate 
Table 11.3 List of recent large earthquakes in the HKH (1993-2015)

\begin{tabular}{|c|c|c|c|c|c|c|c|c|c|}
\hline Year & Month & Country & Name & $\begin{array}{l}\text { Magnitude } \\
\text { (Richter) }^{\mathrm{a}}\end{array}$ & Death $^{\mathrm{a}}$ & $\begin{array}{l}\text { Affected }^{\mathrm{a}} \\
\text { (thousand) }\end{array}$ & $\begin{array}{l}\text { Economic loss } \\
\text { (thousand USD) }^{\mathrm{a}}\end{array}$ & $\begin{array}{l}\text { GDP (current } \\
\text { million USD) }\end{array}$ & $\begin{array}{l}\text { Loss/GDP } \\
(\%)\end{array}$ \\
\hline 1993 & Sep. & India & 1993 Latur & 6.4 & 9,748 & 30 & 280,000 & 278,359 & 0.10 \\
\hline 1998 & May & Afghanistan & $\begin{array}{l}1998 \\
\text { Afghanistan }\end{array}$ & 6.9 & 4,700 & 117 & 10,000 & 2,912 & 0.34 \\
\hline 2005 & Oct. & Pakistan & $\begin{array}{l}2005 \\
\text { Kashmir }\end{array}$ & 7.6 & 73,338 & 5,128 & $5,200,000$ & 117,708 & 4.42 \\
\hline 2008 & May & China & $\begin{array}{l}2008 \\
\text { Sichuan }\end{array}$ & 7.9 & 87,476 & 45,976 & $85,000,000$ & $4,604,285$ & 1.85 \\
\hline 2010 & Apr. & China & 2010 Yushu & 6.9 & 2,968 & 112 & 500,000 & $6,066,351$ & 0.0082 \\
\hline 2015 & Apr. & Nepal & 2015 Nepal & 7.8 & 8,831 & 5,639 & $5,174,000$ & 20,801 & 24.28 \\
\hline
\end{tabular}

${ }^{a}$ EM-DAT: The Emergency Events Database — Université catholique de Louvain (UCL) —CRED, D. Guha-Sapir-www.emdat.be; ${ }^{b}$ UN National Accounts Main Aggregates Database; https://unstats.un.org/unsd/snaama/selbasicFast.asp

motion models and GPS measurements indicate that the India-Eurasia convergence continues today at a rate of about 40-50 $\mathrm{mm}$ per year (de Mets et al. 1994), while the rate of contraction across the Himalaya is estimated to be only $17.52 \pm 2 \mathrm{~mm}$ per year (Bilham et al. 1997). The difference in these rates is absorbed by a combination of thrusting, crustal extension, and strike-slip motion within the Eurasian plate (Armijo et al. 1989; Avouac and Tapponnier 1993; Bhatia et al. 2000; Bilham et al. 2001). Table 11.3 lists large earthquakes with magnitude in excess of $6 \mathrm{Mw}$ in the $\mathrm{HKH}$ from 1993 to 2015. Scenarios based on mathematical models and inferences based on field investigations indicate that the $\mathrm{HKH}$ is a high earthquake risk region (Wesnousky et al. 2017; Bollinger et al. 2004).

Drought: The arid and semi-arid regions of western and northwestern HKH (i.e., the Tibetan Plateau, Afghanistan, northern Pakistan, northwest India, and northwest Nepal) are located in drought-prone areas (Ahmad et al. 2004; Wang et al. 2013). The humid and semi-humid regions also face severe water shortages during the dry months of the year. Drought accounts for only $4 \%$ of all disasters reported globally in the Em-DAT database from 1980 to 2015, yet it accounts for $25 \%$ of all people affected by climate-related disasters (CRED and UNISDR 2016).

Extreme temperatures: Climatological hazards, including extreme temperatures (heat wave, cold wave, and extreme winter conditions) interacting with exposed and vulnerable human and natural systems, can also lead to disasters (IPCC 2012). Extreme heat is a prevalent public health concern throughout the temperate regions of the world. Extreme heat events have been experienced recently in the HKH (see Box 11.3), and it is likely that the length, frequency, and/or intensity of warm spells, including heat waves, will continue to increase. The factors that contribute to physiological and social vulnerability to heat-related illness and death are age, gender, body mass index, and pre-existing health conditions. A common public health approach, early warning systems, and hazard education can play a significant role in reducing exposure and mortality due to extreme temperatures.

\section{Box 11.3 Heat wave in southern Pakistan}

A severe heat wave with temperatures as high as $49 \mathrm{C}$ $(120 \mathrm{~F})$ struck southern Pakistan in June 2015. It caused the deaths of about 2,000 people from dehydration and heatstroke, mostly in Sindh province and its capital city, Karachi. The event followed a separate heat wave in India in May 2015 that killed 2,500 people, including 1,735 in the south Indian state of Andhra Pradesh and 585 people in neighbouring Telangana, the most affected areas.

\subsubsection{Disaster Trends in the HKH}

The Em-DAT database indicates an increasing trend in the HKH in the number of disaster events reported, number of people killed and affected, and economic losses (Fig. 11.7). Between 2000 and 2010, 749 events were reported in the HKH with 399,609 people killed and a huge economic loss. This represents a $143 \%$ increase from 1990 to 2000, in agreement with the report by ADB (2013b) of a rising frequency in natural disasters in Asia and the Pacific.

There is an increasing trend in extreme rain events over India (Goswami et al. 2006). An increase in extreme floods is also evident from the historical records for the Alaknanda River in Uttarakhand, India (see Box 11.4). 
Fig. 11.7 Decadal impact of disasters in the HKH (Source EM-DAT: The Emergency

Events Database-Université catholique de Louvain (UCL) CRED, D. Guha-Sapir-www. emdat.be, Brussels, Belgium)

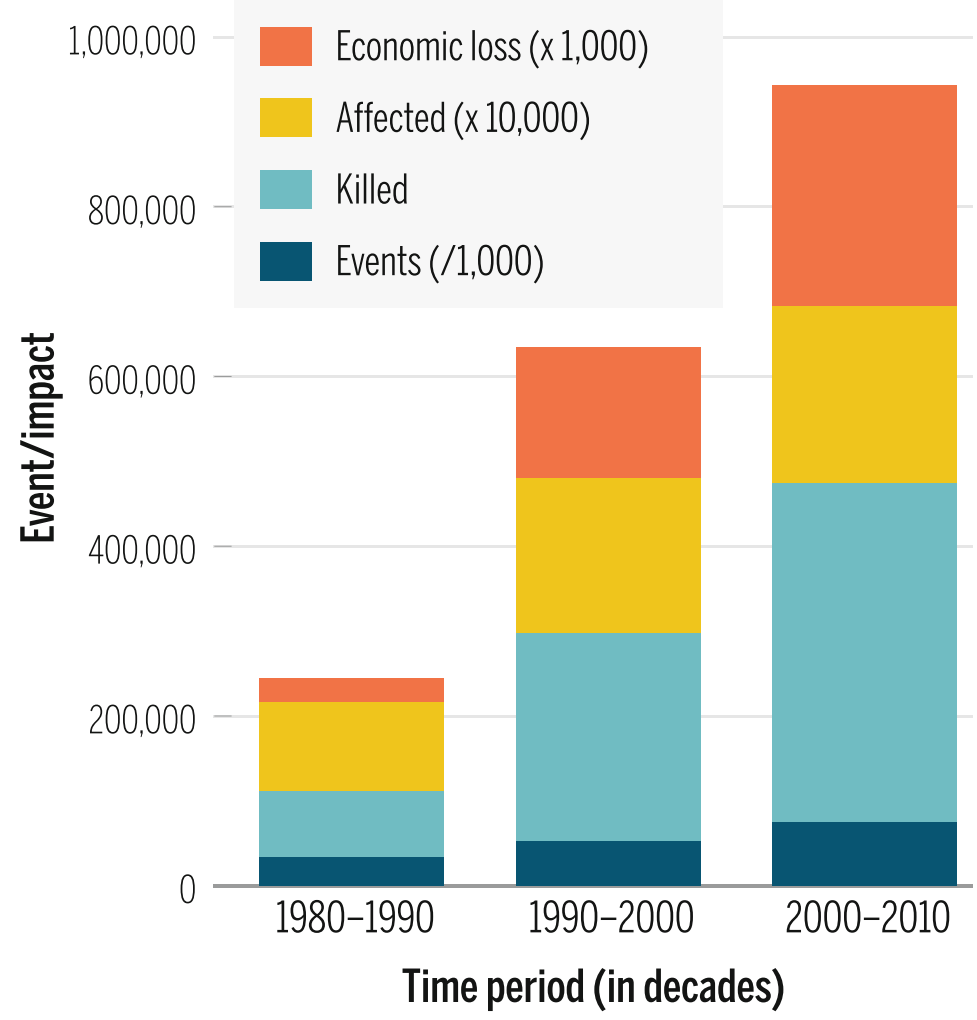

Box 11.4 A history of extreme floods in the Alaknanda River, Uttarakhand, India

Extreme floods occurred in 1894, 1970, and 2013. The most recent flood is fresh in local memory, while the older generation recalls the 1970 flood as one of the forces that kept the Chipko Andolan alive. No one recalls the 1894 deluge. The 2013 flood is thought by some to have been unique and a similar event unlikely to recur. But the history of extreme floods over the past 2000 years, reconstructed from historical accounts and sediments deposited from floodwaters near Srinagar, tells a different story. It is important to note that the oral accounts and sedimentary records are in accordance for the last two extreme floods, so there is confidence that the entire sedimentary record relates to extreme floods. (Wasson et al. 2013; Ziegler et al. 2014).

As can be seen in Fig. 11.8, from roughly 100 to $1700 \mathrm{CE}$, the frequency of floods was relatively constant at approximately one every 200 years. But in the late $1700 \mathrm{~s}$ there was a cluster of five floods, with one every 10 years on average. The most recent three floods in the Alaknanda occurred on average once every 40 years. Most of the floods are likely to have resulted from the confluence of warm and moist monsoon air from the south with cold dry air from the
Arctic. This confluence is likely to become more common as the Arctic warms, and thus flood events are also expected to increase.

Large earthquakes are low-probability but high-impact (Fig. 11.9). However, despite the rare occurrence of earthquakes, there has been a gradual temporal increase in the number of fatalities and level of damage from earthquakes, most of which can be attributed to an increasing concentration of economic development and urbanized habitation in the region. For example, loss of life was similar $(\sim 70,000)$ in the 2005 Kashmir and 2008 Sichuan earthquakes, but the Sichuan disaster, which was closer to urban areas, resulted in an economic loss 16 times greater than in the Kashmir earthquake.

\subsubsection{Linking Primary and Secondary Hazards -The Mountain Perspective}

In the realm of hazard, the term 'cascading' is used to describe the interconnected nature of natural processes in which a primary event triggers a chain of subsequent (secondary and tertiary) hazard event(s). The cascading nature of hazard, and therefore cascading nature of disaster, was appreciated by the global community after the 2011 Tohoku earthquake (Pescaroli and Alexander 2015), in which an 


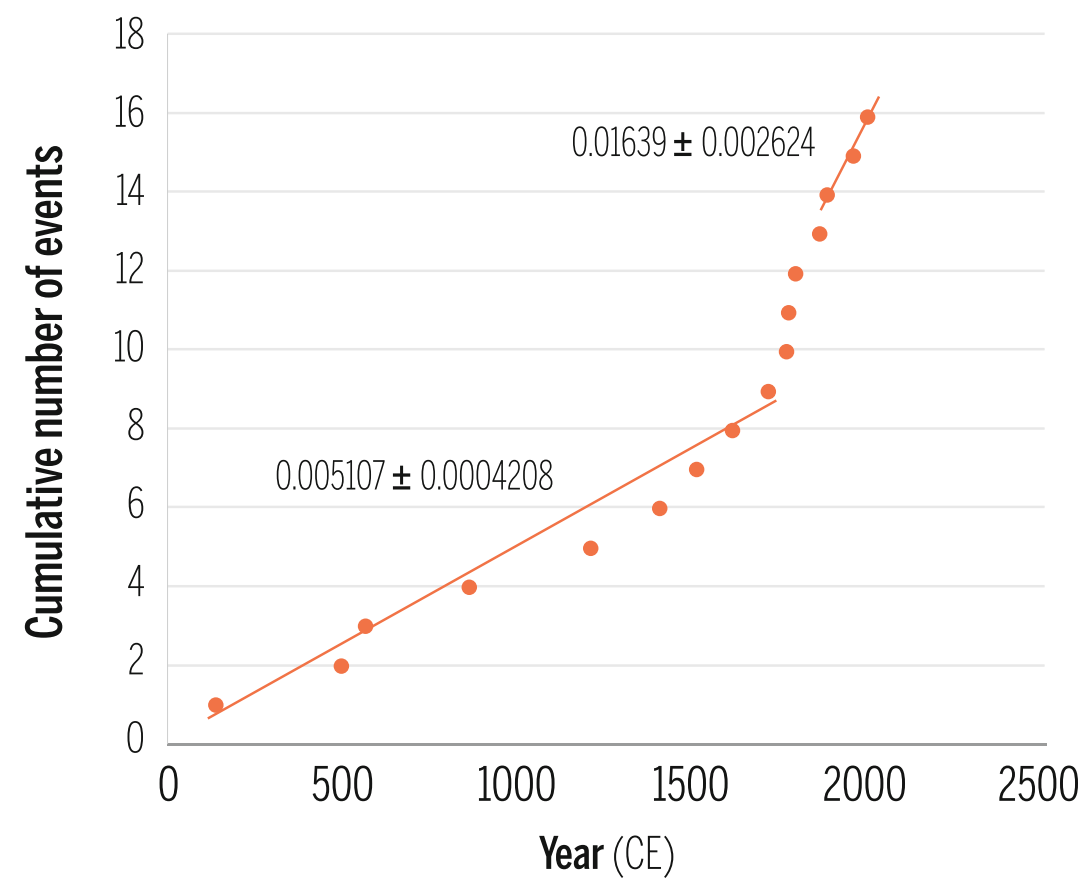

Fig. 11.8 History of extreme floods in the Alaknanda River, Uttarakhand, India (Data source Wasson et al. 2013)

earthquake lead to a tsunami which in turn resulted in a nuclear crisis. Earthquakes can generate landslides that block rivers, causing lakes to form, which in turn can generate a landslide lake outburst flood (LLOF) when the dam fails abruptly as a result of overtopping or piping (Wasson and Newell 2015). Earthquakes can also create landslides and dislodge large sections of glaciers or ice walls, which can then cause a GLOF if they fall into a glacial lake.

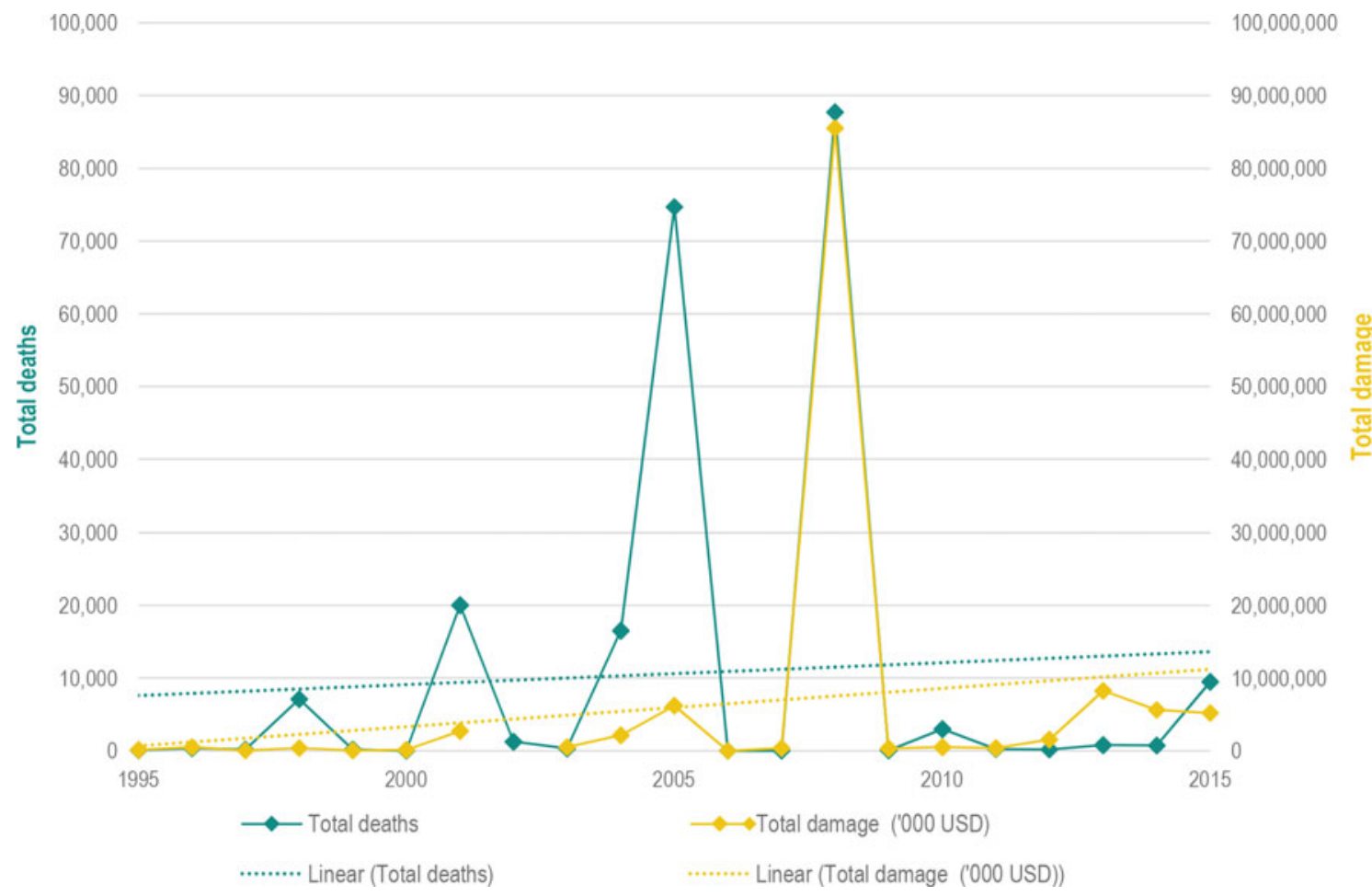

Fig. 11.9 Impact of earthquakes on the number of people killed and total economic losses in the HKH (Source EM-DAT: The Emergency Events Database - Université catholique de Louvain (UCL) — CRED, D. Guha-Sapir—www.emdat.be, Brussels, Belgium) 
GLOFs can erode the toes of hill slopes downstream, adding sediment to the river and raising the riverbed, which in turn can lead to blockages in the river downstream and the formation of small lakes, which themselves can burst out leading to further toe slope erosion downstream. These types of cascading process have been seen during the 1970 flood in the Alaknanda river in Uttarakhand (Wasson and Newell 2015), the 2015 Gorkha earthquake in Nepal (Kargel et al. 2016), following glacial lake outburst floods in Nepal and Bhutan (Higaki and Sato 2012), and following flash floods (Gupta et al. 2016).

Rainfall can also trigger landslides that dam rivers and lead to LLOFs (Gupta and Chalisgoankar 1999), the flows from which undercut the toes of the hill slopes downstream, adding to the landslide and debris flow material and increasing sedimentation along the river bed, thereby raising it. One result is that settlements that were previously high above the riverbed and therefore safe from floods, become at greater risk from future floods. An example of this can be seen at Sonprayag downstream of the Kedarnath hazard zone in Uttarakhand, where the riverbed is now about $30 \mathrm{~m}$ higher than before the 2013 flood. It will be many decades before the riverbed is lowered by sediment evacuation and the flood hazard to local settlements is reduced (Sundriyal et al. 2015; Rautela 2013). Other examples of LLOFs include the Tsatichu landslide in Bhutan (Dunning et al. 2006; Shrestha and Chhophel 2010) and the Jure landslide in the SunKoshi basin, which formed a lake $3 \mathrm{~km}$ long that eventually breached.

The context of cascading hazard and thus cascading disaster is particularly relevant in a mountainous setting like the HKH region, where primary and secondary hazards are closely interrelated. Primary hazards may be geophysical or hydrometerological (e.g., landslides), and trigger secondary hazards, such as landslide dams and subsequent outburst floods (Gill and Malamud 2016). For example, the 2015 Nepal earthquake resulted in more than 4,000 landslides (Kargel et al. 2016). Table 11.4 shows some examples of primary and secondary hazards in the HKH region.
The examples of cascading hazards indicate clearly that disaster risk reduction (DRR) plans and policies in the $\mathrm{HKH}$ region will be ineffective unless they take a holistic approach which clearly appreciates the interconnectedness of different hazard events. It is important to recognize that a cascading chain of events can unfold immediately, but may also take place after a substantial lapse of time. To address these issues, it is essential to have a multi-hazard early warning system.

\subsection{Vulnerability: Physical, Social, Economic, and Environmental Dimensions}

Disaster risks are a function of interplay among three key elements: hazards, exposure, and vulnerability (IPCC 2012). The term vulnerability is a state of susceptibility to harm and assumes different connotations depending on the context (Ciurean et al. 2013). A plurality of views and meanings of the term 'vulnerability' are explicit in the different ways the natural science and social systems frame the term and construct measurement frameworks. Similarly, climate change, environmental change, and disaster risk reduction all possess different visions of vulnerability. The 'vulnerability' perspective in disasters is defined as "the characteristics of a person or group and their situation that influences their capacity to anticipate, cope with, resist, and recover from the impact of a natural hazard" (Donner and Rodríguez 2011). The life safety and livelihoods of mountain communities in the HKH region are constantly threatened by multiple geological and hydrological hazards. Climate change, poor land use practices, and forest and land degradation are further exacerbating these risks, especially the risk of hydrological hazards (Shaw and Nibanupudi 2015). There is a clear indication that not only is the frequency of such hazards increasing with time, but also their intensity and impact on the lives and livelihood of people is increasing in severity. The frequency and intensity of disasters is pushing the resilience and recovery capacity of communities,

Table 11.4 Primary and secondary hazards in the mountains of the $\mathrm{HKH}$

\begin{tabular}{l|l|l}
\multicolumn{2}{l|}{ Type of hazard } & Occurrence \\
\hline Primary & Secondary & \\
\hline Earthquake & Landslides & 2005 Kashmir earthquake in Pakistan and India \\
\hline Landslide & $\begin{array}{l}\text { Landslide dam and subsequent outburst } \\
\text { flood }\end{array}$ & 2008 Wenchuan earthquake in China \\
\cline { 2 - 3 } & 2015 Gorkha earthquake in Nepal \\
\hline Flood & $\begin{array}{l}\text { Erosion and deposition (aggradation and } \\
\text { degradation), sand casting (deposition) }\end{array}$ & 2010 Pakistan: Hunnza Attabad landslide \\
\hline
\end{tabular}


governments, and institutions to the limit. Climate change is now expected to exacerbate disasters and lead to greater destruction in the future in the HKH region, with potentially profound implications (see Chap. 3: Climate Change in the Hindu Kush Himalaya).

This section focuses on vulnerability in the context of disaster risk management, which is framed as the potential for loss caused by natural hazards, and is a function of exposure, susceptibility, and coping capacity. Birkmann et al. (2013) describe three core thematic dimensions of vulnerability.

Physical dimension: potential for damage to physical assets, including built-up areas, infrastructure, and open spaces.

Social dimension: propensity for human wellbeing to suffer as a result of disruption to individuals (mental and physical health) and the collective social systems (health, education services), and the characteristics of these systems (e.g., gender, marginalization of social groups).

Economic dimension: propensity for loss of economic value from damage to physical assets and/or disruption of productive capacity.

According to UNISDR, vulnerability is "determined by physical, social, economic, and environmental factors or processes, which increase the susceptibility of $\mathrm{a}[\mathrm{n}$ ] [individual] or community [assets or systems] to the impact[s] of hazards" (United Nations 2016). The World Bank and IPCC include governance as the fifth factor influencing vulnerability, and suggest it is particularly important in regions like South Asia, where governance is generally weak. The definition implies that vulnerability is a condition that depends on multiple factors. Mountain systems are inherently challenged by what Jodha (1992) calls 'mountain specificities', which aggravate vulnerability to disaster and include, among others, constraining features such as accessibility, marginality, and fragility. The vulnerability of these countries to disasters is characterized by complex interactions between the natural and socioeconomic conditions (Elalem and Pal 2015).

\subsubsection{Physical Factors}

Physical vulnerability refers to the vulnerability that stems from the limitations posed by the physical characteristics of the exposed elements, for example, population density, remoteness, limited access to critical amenities, legal challenges, proximity to hazard zones, and design and quality of infrastructure. Table 11.5 shows the percentage of area and population exposed to hazards in the HKH countries. The least vulnerable communities are those with lower levels of exposure that have good access to emergency response services and comparatively high-quality infrastructure.
Table 11.5 Percentage of area and population exposed to hazards by HKH country

\begin{tabular}{l|l|l|l}
\hline Country & $\begin{array}{l}\text { Percent of } \\
\text { total area } \\
\text { exposed }\end{array}$ & $\begin{array}{l}\text { Percent of } \\
\text { population } \\
\text { exposed }\end{array}$ & $\begin{array}{l}\text { Maximum } \\
\text { number of } \\
\text { hazard types }\end{array}$ \\
\hline Afghanistan & 11.1 & 29.5 & 3 \\
\hline Bangladesh & 35.6 & 32.9 & 4 \\
\hline Bhutan & 20.1 & 29.2 & 4 \\
\hline China & 8.4 & 15.7 & 3 \\
\hline India & 10.5 & 10.9 & 4 \\
\hline Myanmar & 10.7 & 10.4 & 4 \\
\hline Nepal & 60.5 & 51.6 & 3 \\
\hline Pakistan & 5.6 & 18.2 & 2
\end{tabular}

${ }^{\mathrm{a}}$ Cyclones, drought, earthquakes, floods, landslides (Source World Bank 2005)

Table 11.6 Quality of infrastructure services in the HKH countries (World Economic Forum 2014)

\begin{tabular}{l|l|l|l|l}
\hline Country & $\begin{array}{l}\text { Overall } \\
\text { infrastructure }\end{array}$ & Roads & $\begin{array}{l}\text { Air } \\
\text { transport }\end{array}$ & $\begin{array}{l}\text { Electricity } \\
\text { supply }\end{array}$ \\
\hline World & 4.23 & 4.02 & 4.36 & 4.50 \\
\hline Bangladesh & 2.82 & 2.88 & 3.02 & 2.55 \\
\hline Bhutan & 4.63 & 4.31 & 3.51 & 5.85 \\
\hline China & 4.36 & 4.61 & 4.72 & 5.22 \\
\hline India & 3.75 & 3.79 & 4.27 & 3.43 \\
\hline Nepal & 2.93 & 2.90 & 2.92 & 1.83 \\
\hline Pakistan & 3.32 & 3.81 & 3.92 & 2.07
\end{tabular}

Note Scores on a scale of 1 (low) to 7 (high)

The overall quality of infrastructure in Bangladesh, India, Nepal, and Pakistan is lower or much lower than the global average, whereas in Bhutan and China it is slightly better (Table 11.6; World Economic Forum 2014). This is true for roads, air transport, and electricity services. The variation in quality of infrastructure among the HKH countries is partly due to inadequate levels of investment (World Bank 2013). In 1973-2009, Bangladesh, India, and Pakistan spent only six percent of their Gross Domestic Product (GDP) on average on infrastructure, and Nepal only five percent. The World Bank suggested that all these countries will need to invest a higher share of GDP in infrastructure in 2011-2020.

\subsubsection{Social Factors}

Social vulnerability refers to the human vulnerability resulting from the characteristics inherent in social interactions, institutions, and systems of cultural values which determine the capacity of groups and individuals to deal with disasters and hazards, and is based on the position and situation of people within the physical and social worlds (Dow 
1992). Over the years, the term 'social vulnerability' has taken on a broader and increasingly interdisciplinary meaning to incorporate the idea that vulnerability is not just an inherent characteristic of certain groups, but rather it is produced, underlied, and driven by a wide variety of conditions. Therefore, vulnerability is not just defined with respect to exposure to hazards, but also by numerous socioeconomic factors. Some common factors determining social vulnerability include social and economic inequality, marginalization, social exclusion, lack of preparedness and adaptive capacity, and discrimination by gender, social status, disability, and age (Bergstrand et al. 2015). Affluent communities with equity in all spheres of social practice are generally less vulnerable than poor communities where inequality is prevalent. Efforts to reduce vulnerability must not, therefore, be confined to reducing hazard exposure only, but should also include the social systems within which vulnerability is produced (Blaikie et al. 1994).

The UN's Human Development Index (HDI) is one of the most widely-used indicators for measuring quality of life, and provides an interesting starting point for evaluating the $\mathrm{HKH}$ countries (Table 11.7). Generally, the HKH countries (except China) have lower HDI values than the world average, which indicates that these populations have higher than average social vulnerability. Education and gender inequality are particularly pronounced in the $\mathrm{HKH}$ countries, whereas income inequality is high, except in China and Bangladesh.

Focusing on local and indigenous knowledge is also important for mountain communities, which usually have a rich experience and knowledge linked to their lifestyles and livelihoods. Indigenous knowledge forms the basis of community coping practices, builds up resilience to disasters, and plays an important role in disaster risk reduction. Both in saving lives during a disaster, and helping others recover post disaster, rules built on the basis of indigenous knowledge can help a community to cope more easily (Shaw and Nibanupudi 2015). Combining indigenous and local knowledge with external expertise is vital for resilience.

\subsubsection{Economic Factors}

The premise that disaster affects rich and poor people differently is based on the idea that economically stronger communities have options to invest in resilient infrastructure, and are economically empowered to invest in better access to emergency services. Thus the level of vulnerability is highly dependent upon the economic status of an individual, the community, and the nation. While disasters cause more economic damage and greater loss to infrastructure in developed nations, they generally take a larger number of human lives in developing countries (Pusch 2004). Economic vulnerability is particularly important in building resilience to disaster and reducing exposure to hazards, and is thus especially important in the HKH, where five of the eight countries (Afghanistan, Bangladesh, Bhutan, Myanmar, and Nepal) are classified as Least Developed Countries (United Nations 2017).

Table 11.8 shows the values for the Multidimensional Poverty Index (MPI) in the HKH countries in 2015. The MPI is measure of acute poverty covering more than

Table 11.7 Human development index and inequalities (UNDP 2016)

\begin{tabular}{|c|c|c|c|c|c|c|c|c|c|}
\hline \multicolumn{10}{|c|}{ Human Development Index and Inequalities } \\
\hline \multirow[t]{3}{*}{ Country } & \multirow{2}{*}{$\begin{array}{l}\text { Human } \\
\text { Development } \\
\text { Index (HDI) } \\
\text { Value }\end{array}$} & \multirow{2}{*}{ 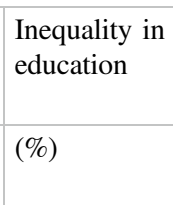 } & \multirow{2}{*}{ 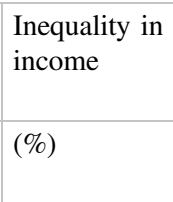 } & \multicolumn{3}{|c|}{ Income inequality } & \multirow{2}{*}{$\begin{array}{l}\text { Gender } \\
\text { Development } \\
\text { Index } \\
\text { Value }\end{array}$} & \multicolumn{2}{|c|}{$\begin{array}{l}\text { Gender } \\
\text { Inequality } \\
\text { Index }\end{array}$} \\
\hline & & & & $\begin{array}{l}\text { Quintile } \\
\text { ratio }\end{array}$ & $\begin{array}{l}\text { Plama } \\
\text { ratio }\end{array}$ & $\begin{array}{l}\text { Gini } \\
\text { coefficient }\end{array}$ & & Value & Rank \\
\hline & 2014 & 2014 & 2014 & $2005-2013$ & $2005-2013$ & 2005-2013 & 20144 & 2014 & 2014 \\
\hline China & 0.727 & & 29.5 & 10.1 & 2.1 & 37 & 0.943 & 0.191 & 40 \\
\hline India & 0.609 & 42.1 & 16.1 & 5 & 1.4 & 33.6 & 0.795 & 0.563 & 130 \\
\hline Bhutan & 0.605 & 44.8 & 19.6 & 6.8 & 1.8 & 38.7 & 0.897 & 0.457 & 97 \\
\hline Bangladesh & 0.57 & 38.6 & 28.3 & 4.7 & 1.3 & 32.1 & 0.917 & 0.503 & 111 \\
\hline Nepal & 0.548 & 41.4 & 15.1 & 5 & 1.3 & 32.8 & 0.908 & 0.489 & 108 \\
\hline Pakistan & 0.538 & 44.4 & 11.6 & 4.1 & 1.1 & 29.6 & 0.726 & 0.536 & 121 \\
\hline Myanmar & 0.536 & 19.4 & & & & & & 0.413 & 85 \\
\hline Afghanistan & 0.465 & 44.8 & 10.8 & 4 & 1 & 27.8 & 0.6 & 0.693 & 152 \\
\hline $\begin{array}{l}\text { Developing } \\
\text { countries }\end{array}$ & 0.66 & 32.3 & 24.5 & - & - & - & 0.899 & 0.478 & - \\
\hline World & 0.711 & 26.8 & 24 & - & - & - & 0.924 & 0.449 & - \\
\hline
\end{tabular}

Source UNDP Human Development Index http://hdr.undp.org/en/content/human-development-index-hdi 
Table 11.8 Value of the Multidimensional Poverty Index in the HKH countries, 2015 (UNDP 2016; Alkire and Robles 2017)

\begin{tabular}{l|l}
\hline Country & MPI \\
\hline Afghanistan & 0.295 \\
\hline Bangladesh & 0.196 \\
\hline Bhutan & 0.119 \\
\hline China & 0.017 \\
\hline India & 0.191 \\
\hline Myanmar & 0.134 \\
\hline Nepal & 0.126 \\
\hline Pakistan & 0.230 \\
\hline
\end{tabular}

100 developing countries. It assesses poverty at the individual level and complements traditional income-based poverty measures by capturing the severe deprivations that each person faces with respect to education, health and living standards (Alkire and Robles 2017). With the exception of China, the HKH countries rank high in MPI, which suggests high economic vulnerability.

\subsubsection{Environmental Factors}

The environmental conditions also play a role in determining a community's vulnerability to disaster. Badly managed environments create unsafe situations and thereby increase vulnerability to disaster. Some of the determinants of environmental vulnerability are poor environmental management, overconsumption of natural resources, degraded ecosystems, decline in risk-regulating ecosystem services, and climate change (ISDR and UNEP 2007). Depletion of natural resources (for example, wetlands) exposes people and infrastructure to natural hazards like floods and storm surges.

The HKH is both a climate change hotspot and a densely populated region, a factor contributing to the depletion and degradation of natural resources, and a pathway to increased vulnerability.

\subsubsection{Gender Dimensions}

Disasters and climate extremes have differential effects on women, men, and third gender people in all social categories. The pre-existing social structures and norms create greater stress on women and marginalized groups further exacerbating their vulnerability. Records of natural disasters in the Himalayan region over the last few decades show that women are at greater risk of dying than men (Mehta 2007). More women than men die when disasters strike as a result of women's lack of access to information, mobility, and decision-making power and inequitable access to resources and training; as well as gender-based sociocultural norms and barriers, conventional gender responsibilities, and high rates of male outmigration (Mehta 2007; Ariabandhu 2009; Nellemann et al. 2011). In mountain communities, women play a crucial role in protecting, nurturing and sustaining natural resources. At the same time, they are often disadvantaged in terms of benefit sharing, accessing productive resources, and participation in organizational structures and decision making, and are exposed to increased risks associated with climate change during disasters and loss of income from climate shocks (Nibanupudi and Khadka 2015). For example, during the 1991 cyclone in Bangladesh, the mortality rate for women was three times higher than for men (UNEP 1997; Twigg 2009). Gender inequities can be evident in a lack of, or inadequate, early warning information and evacuation procedures and arrangements targeting women. Knowledge of early warnings and the decision to evacuate may be the exclusive domain of men. In some cases, women may be ill-informed about natural hazards and not allowed to make the decision to evacuate (Stark et al. 2013). A UNEP report (UNEP 1997) concluded that the early warning signals had not reached many women downstream.

Vulnerability is particularly high when poverty intersects with discrimination, whether because of gender, caste, ethnicity, or other reasons. This is especially true for women and low caste people (Adger and Kelly 1999; Brooks and Adger 2005; Aguilar et al. 2015). During the 2015 Nepal earthquake, more women than men died in all the affected districts except Kathmandu (Rasul et al. 2015). Fewer opportunities exist for education, political involvement, and access to information, markets, and a myriad of other resources (Ariyabandu and Wickramasinghe 2003). Considering vulnerability factors such as social roles and access to resources and information, women are more vulnerable to climate change and disasters than men. Women also know less than men about their communities' disaster prevention and mitigation projects. Furthermore, natural disasters and climate change often exacerbate existing inequalities and discrimination in such a way that women and girls become more vulnerable and are at higher risk of gender-based violence, sexual harassment, exploitation, abuse, trafficking, and rape during displacement caused by major disasters such as flood, drought, or earthquake.

Men and women possess valuable, but different, knowledge, skills, experience, and coping capacities. However, the strengths and capabilities of women are often ignored in policy decisions and in formal arrangements related to mitigation and recovery. Policy makers and planners generally give little attention to the social barriers and constraints that hinder women's participation in capacity building and their access to information that could help achieve better preparedness. Gender differences are manifested in the disproportionately poorer health and nutritional status, lower levels of access to formal literacy and education, higher levels of 
economic poverty, higher morbidity/mortality rates, and high workloads of women compared to men, as well as extremely low rates of property ownership, decision making, and representation in governance institutions (Leduc 2011). Adopting a gender-sensitive early warning system approach with appropriate policies in place will help in reducing the disaster mortality of women and contribute to reducing the adverse impact of flood disasters (Shrestha et al. 2014). To have disaster-resilient communities, the participation of both men and women at various levels is essential. Inequalities that exist in society are often strengthened during disaster, and this must be kept in mind when collecting data and analysing and formulating disaster resilience plans and activities (Shaw and Nibanupudi 2015). A gender-sensitive approach that not only recognises the vulnerabilities of women, but also works towards enhancing their resilience and strengthening their ability through awareness raising and capacity building initiatives, is needed to respond effectively to disasters.

\subsection{Risk Assessment}

Risk is the likelihood of harmful consequences of natural hazards arising from the interaction among hazards, vulnerable elements, and the environment. As discussed earlier, disaster risk depends on the probability that different kinds and intensities of hazards will occur, whether the elements are exposed to these hazards, and the level of vulnerability of the elements exposed to the hazards (World Bank 2005). Risk information forms the cornerstone of any risk reduction agenda; thus, awareness of existing and anticipated risk is essential to guide disaster risk reduction interventions, strategies, and policies. The cost effectiveness of protection measures can be evaluated based on the calculated risk. Risk assessment involves the identification, quantification, and characterization of threats to human health and the environment. But risk analysis is as much a political enterprise as a scientific one, and public perception of risk also plays a role in risk analysis, bringing the issues of values, process, power, and trust into the overall picture (Slovic 1999).

\subsubsection{Understanding Risk}

Risk assessment to understand the risk situation is the first step to augment risk-informed decision making and development. While many excellent risk assessments exist, there are relatively few risk assessments in practice. Because the $\mathrm{HKH}$ is characterized by natural hazard hotspots and with the exception of China, a low HDI, it is considered a high disaster risk region. According to the indicators for hydro meteorological hazards and disaster risk developed in the
Asian Water Development Outlook (AWDO) 2013, India in the HKH country is most prone to hydro meteorological hazards, followed by China, Bangladesh, Pakistan, and Nepal - no indicators available for Afghanistan, Bhutan, and Myanmar (ADB 2013a). The AWDO report considers vulnerability as a function of exposure, basic vulnerability, soft coping capacity, and hard coping capacity. Bangladesh faces the highest level of exposure to hazards, followed by Pakistan, Nepal, India, and China. Basic vulnerability, measured by proxies such as poverty levels, among others, is also high in Bangladesh, Pakistan, and Nepal compared to China and India. Soft coping capacity, measured by proxies such as literacy rate, among others, is lowest in Nepal and highest in China, with Bangladesh, Pakistan, and India falling in between. Finally, hard coping capacity, measured by proxies such as infrastructure facilities, is lowest in Nepal, with other countries having similar indicators.

Many global risk assessment exercises mark the $\mathrm{HKH}$ countries as highly vulnerable (Garschagen et al. 2016) (Table 11.9). The World Risk Index ranks 171 countries according to their risk of becoming a victim of a disaster as a result of five natural hazards (earthquakes, cyclones, floods, droughts, and sea-level rise). It uses 28 individual indicators, related to exposure and 23 related to elements representing vulnerability (susceptibility, lack of coping capacity, lack of adaptive capacity). The World Risk Index is calculated by multiplying exposure and vulnerability. The higher the risk index value, the greater the risk, and vice versa. Details of the risk calculation approach and indicators used can be found at www.WorldRiskReport.org.

The HKH region already faces a high natural hazard risk, but the impacts of climate change will further aggravate the situation, as a result of the loss and fragmentation of habitats, a reduction in forest biodiversity, the degradation of wetland and riverine island ecosystems, a decline in forage and fodder resources, a reduction in agrobiodiversity, an increase in forest fires, soil fertility degradation, changes in land use patterns, and an increased variability in agricultural productivity (Tse-ring et al. 2010). As in other mountain regions, the Hindu Kush Himalaya have experienced above-average warming (see Chap. 4: Exploring Futures of the Hindu Kush Himalaya Scenarios and Pathways; Nogués-Bravo et al. 2007), which has adversely impacted freshwater, primarily snow, glacier, and permafrost (Yao et al. 2012). Climate change impact modelling projects a scenario of dwindling water availability (Immerzeel et al. 2010) that could undermine the socioeconomic fabric of the downstream societies.

The HKH has experienced rapid environmental changes and it is widely believed that the region will be one of the planet's hot spots for future climate change impacts (Maplecroft 2011). Mountain communities and their livelihoods are sensitive to such changes, which will have a 
Table 11.9 Risk index in the HKH countries (2016) (Garschagen et al. 2016)

\begin{tabular}{|c|c|c|c|c|c|c|c|}
\hline Country & $\begin{array}{l}\text { World Risk Index } \\
(\%)\end{array}$ & $\begin{array}{l}\text { Exposure } \\
(\%)\end{array}$ & $\begin{array}{l}\text { Vulnerability } \\
(\%)\end{array}$ & $\begin{array}{l}\text { Susceptibility } \\
(\%)\end{array}$ & $\begin{array}{l}\text { Lack of coping capacity } \\
(\%)\end{array}$ & $\begin{array}{l}\text { Lack of adaptive capacity } \\
(\%)\end{array}$ & Rank \\
\hline Afghanistan & 9.50 & 13.17 & 72.12 & 56.05 & 92.85 & 67.48 & 41 \\
\hline Bangladesh & 19.17 & 31.70 & 60.48 & 38.23 & 86.36 & 56.85 & 5 \\
\hline Bhutan & 7.51 & 14.81 & 50.70 & 29.43 & 73.77 & 48.90 & 60 \\
\hline China & 6.39 & 14.43 & 44.29 & 22.81 & 69.86 & 40.18 & 85 \\
\hline India & 6.64 & 11.94 & 55.60 & 35.79 & 80.22 & 50.78 & 77 \\
\hline Myanmar & 8.90 & 14.87 & 59.86 & 35.63 & 87.00 & 56.93 & 42 \\
\hline Nepal & 5.12 & 9.16 & 55.91 & 38.05 & 81.05 & 48.64 & 108 \\
\hline Pakistan & 6.96 & 11.36 & 61.26 & 35.04 & 86.26 & 62.48 & 72 \\
\hline
\end{tabular}

variety of impacts on human wellbeing. Primary sector livelihoods such as agricultural livelihoods have become increasingly uncertain and risky and, because of inadequate resources, poor households have especially limited adaptation options and are simply coping (Gentle and Maraseni 2012). Mountain areas are challenging living spaces, and mountain communities have a long history of adapting to extreme conditions. Nevertheless, traditional adaptation mechanisms are often insufficient to cope with recent socioeconomic and environmental changes (Jodha 1997), which have considerably increased the challenges for mountain people in securing their livelihoods ( $\mathrm{O}^{\prime}$ Brien and Leichenko 2000).

In developing countries, economic development in mountain regions already lags behind that in the lowlands, foothills, and urban areas (Tanner 2003). Climate change is expected to exacerbate the existing challenges faced by mountain people and their environments, intensify some existing hazards, and result in the emergence of new hazards (O’Brien and Leichenko 2000; Sonesson and Messerli 2002; Macchi et al. 2011). These processes will intensify the exposure component of vulnerability. The sensitivity component will include environmental aspects embedded in the biophysical features of a region and social elements that are closely linked to the nature and range of available livelihood options (Jodha 1997), as well as access to resources (Adger and Kelly 1999; Brooks and Adger 2005; Aguilar et al. 2015).

\subsubsection{Risk Informed Decision Making}

Risk assessment remains few in practice, which poses a challenge to risk-informed decision making. The Government of Nepal as a party to the United Nations Framework Convention on Climate Change (UNFCCC), has initiated a National Adaptation Plan (NAP) formulation plan, which is an excellent example of moving towards risk-informed decision making (MOPE 2017). The NAP has adopted a vulnerability and risk assessment (VRA) framework based on the Fifth Assessment Report (AR5) of the Intergovernmental Panel on Climate Change (IPCC).

Other challenges in translating risk knowledge to practice are inadequate granularity of information and what has been termed 'spatial scale challenges' by Carr et al. (2015). The Consultative Workshop on Landslide Inventory, Risk Assessment, and Mitigation in Nepal (Gurung et al. 2017) identified spatial scale challenges and inconsistency in methodology as two of the main setbacks to implementing risk assessment results. Strategic decision making at the national and sub-national levels has different information needs compared to local level decision making, which is more operational in nature. There is an obvious gap in national and sub-national risk assessment, as many assessments are done at a micro scale for specific sites/areas. The novel methodology developed and tested in northeast Brazil to reveal regional vulnerability using global level information, using a "combination of both clustering and qualitative dynamics" (Sietz 2014; Sietz et al. 2017), should be adopted. These assessments enable cross-scale comparison of risks and vulnerability and are well-suited to inform decision making at multiple scales.

Another challenge in the $\mathrm{HKH}$ is that assessment is skewed more towards hazards than vulnerability and risk. Risk assessment as a process is still far from being mainstreamed into government systems, and is mostly done through project support. This has resulted in risk assessment being conducted in pockets and based on different methods favoured by different project proponents.

There is a need to develop and promote systematic assessment methods and uniform risk assessment protocols (Gaire et al. 2015; ICIMOD 2016; SDMC 2011). The SAARC Comprehensive Disaster Management Framework approved by the Fourteenth SAARC Summit in New Delhi held 3-4 April 2007 identified "developing standards and methodology for hazard and vulnerability assessment..." as one of the pathways necessary to develop and implement risk reduction strategies (retrieved from http:// saarc-sdmc.nic.in/framework.asp). 


\subsection{A Framework for Policies to Reduce Risk and Enhance Resilience}

In this section we propose a disaster risk reduction framework to reduce risk and enhance resilience in the $\mathrm{HKH}$, and address the key issues for mountain and downstream communities. The framework we propose is based on the principles of the 1994 Yokohama Strategy and Plan of Action, the 2005 Hyogo Framework of Action, UNDP's 2007 Human Development Report (UNDP 2007), and the Sendai Framework for Disaster Risk Reduction 2015-2030.

The focus in this section is on building resilience to disasters, including those that are climate-induced, and not on climate change adaptation (which is discussed in Chap. 13: Adaptation to Climate Change). The concepts, goals, and processes of climate change adaptation, however, have much in common with disaster risk management (Lavell et al. 2012; Schipper 2009), especially on matters related to managing climate-induced disasters. It may even be possible to conceptualize climate change adaptation starting from disaster risk management, with a clear understanding of the differences between the two (Vaidya et al. 2014). But here we have limited our scope to building resilience to disasters.

\subsubsection{A Framework for Reducing Risk and Increasing Resilience to Disasters}

Our disaster risk reduction framework for the $\mathrm{HKH}$ has four principal elements: Information, Infrastructure, Institutions, and Insurance.

Information: Since the $\mathrm{HKH}$ is a hotspot for both hydrometeorological and geophysical hazards, developing a strong knowledge base on extreme weather events and seismic activities in the region is vital to understanding how to increase resilience. In addition, hazard maps for communities and real-time information systems can substantially reduce vulnerability to potential hazards through early warning systems and prudent land use planning, especially in situations where financial protection measures, such as insurance, are not in place. The value a society places on such information may depend on their perception of riskand their perception may, in turn, depend on the information they have available to sense the likelihood of the hazards.

Often, the government shows a willingness to invest in information systems soon after a hazard event occurs. For example, after a massive earthquake devastated two of its districts in 1993, Maharashtra became the first state in India to implement a comprehensive plan, complete with a state-of-the-art satellite-linked computer network connecting various civic bodies, collectorates, and blocks in the state (Vatsa 2002). It would be much better, however, if such initiatives could be proactive rather than reactive.

Data and information are a prerequisite for informed decision making for disaster risk reduction. Every forecast has some uncertainty and it is important that this is communicated and explained to the decision makers. A broad range of environmental and social data and information may be shared to promote transboundary cooperation for better river basin planning and management and to address climate change (Chenoweth and Feitelson 2001; Grossman 2006; Gerlak et al. 2010). Sharing data and information builds trust and confidence amongst countries and provides a common understanding of the issues, which may result in agreement, joint implementation, and improved transboundary cooperation (Shrestha et al. 2015; Blumstein et al. 2016). In the $\mathrm{HKH}$, there has been some progress with the HYCOS system under the World Meteorological Organization's WHYCOS framework in which countries share real-time hydrometeorological data for flood risk reduction (Shrestha et al. 2015) and work towards an end-to-end early warning system. Working in partnership with several regional and international partners, ICIMOD offers a regional platform for utilizing the latest advances in space technology and GIS (geographic information systems) applications to address disaster challenges and to support risk identification and early warning systems.

It is important to note that after disasters occur, funds for recovery do become available from various sources, both internal and external. But the same quantum of money could be more efficiently and effectively used by mainstreaming it, in part, to development activities that help communities with hazard maps, real-time information systems, and communication channels that reach the last mile before a disaster happens - so that they can be better prepared and thus save lives and livelihoods. The Asia regional plan for implementation of the Sendai framework for disaster risk reduction 2015-2030 includes a two-year action plan for 2017 to 2018 which seeks to strengthen existing regional mechanisms to reduce risk and enhance early warning and preparedness for transboundary disasters. The Sendai Framework may also help to attract funds for generating information on risk. This is a significant change in priority from the 2005 Hyogo Framework, where risk assessment was identified as the second priority (see Box 11.5).

Infrastructure: Investments may also be necessary to create hazard-resilient critical infrastructure such as hospitals for healthcare services and school buildings for use as community shelters after hazardous events. Similar investments in road networks for access to settlements, and communications systems for information flow may also be necessary 
to ensure connectivity immediately after disasters. Furthermore, critical infrastructure such as water supply systems and electric power plants should be made climate-resilient, and standards for rebuilding structures after earthquakes should be improved.

It is important to note that there was an implicit shift towards a balance between structural and non-structural measures after the announcement of the Hyogo Framework. But the emphasis on the importance of balanced investments in structural measures has reappeared with the promotion of 'Build Back Better' as Priority 4 of the Sendai Framework, and for investment in disaster-resilient critical facilities as Priority 3 on disaster risk reduction. The same priority also highlights investments in ecosystem-based natural resource management approaches.

Institutions: Resources need to be invested in capacity building through training programmes for formal and informal institutions as well as pre-positioning of stockpiles at the local level. Appropriate policies and mechanisms also need to be developed for supportive interfaces between these institutions at both the national and local levels. Institutional arrangements supported by communications technologies and clear message contents must be developed for end-to-end communications up to the last mile. For example, the ability to send alerts for flood hazards or deliver relief measures after earthquakes is crucial.

The Hyogo Framework's first priority was the establishment of institutions for disaster risk reduction: "Ensure that disaster risk reduction is a national and a local priority with a strong institutional basis for implementation." In view of the weaknesses of the institutional basis for converting national policy into local action (Oxley 2013), the Sendai Framework, in its Priority 2 on strengthening disaster risk governance, has emphasized the need "to carry out an assessment of the technical, financial, and administrative disaster risk management capacity to deal with the identified risks - at the local and national levels."

In addition, the Sendai Framework also explicitly mentions the need to develop institutions "to promote transboundary cooperation to enable policy and planning for the implementation of ecosystem-based approaches," which has high relevance in the HKH. Transboundary cooperation can be enhanced at the national and local levels between two or more countries. The Sendai Framework clearly highlights, in Priority 3 , the need to promote mechanisms for disaster risk transfer, risk sharing, and retention, and financial protection to reduce the financial impact of disasters. In the Hyogo Framework, Priority 4 discusses the need to develop financial risk-sharing mechanisms (see Box 11.5).

\section{Box 11.5 Priorities of the global agenda: the Hyogo and the Sendai frameworks}

\begin{tabular}{|c|c|c|}
\hline $\begin{array}{l}\text { Priorities } \\
\text { of the } \\
\text { Global } \\
\text { Agenda }\end{array}$ & $\begin{array}{l}\text { Hyogo Framework of } \\
\text { Action 2005-2015: } \\
\text { Building the Resilience of } \\
\text { Nations and } \\
\text { Communities to Disasters }\end{array}$ & $\begin{array}{l}\text { Sendai Framework for } \\
\text { Disaster Risk } \\
\text { Reduction 2015-2030 }\end{array}$ \\
\hline Priority 1 & $\begin{array}{l}\text { Ensure that disaster risk } \\
\text { reduction is a national } \\
\text { and a local priority with a } \\
\text { strong institutional basis } \\
\text { for implementation. }\end{array}$ & $\begin{array}{l}\text { Understanding disaster } \\
\text { risk }\end{array}$ \\
\hline Priority 2 & $\begin{array}{l}\text { Identify, assess, and } \\
\text { monitor disaster risks and } \\
\text { enhance early warning. }\end{array}$ & $\begin{array}{l}\text { Strengthening disaster } \\
\text { risk governance to } \\
\text { manage disaster risk }\end{array}$ \\
\hline Priority 3 & $\begin{array}{l}\text { Use knowledge, } \\
\text { innovation, and education } \\
\text { to build a culture of } \\
\text { safety and resilience at all } \\
\text { levels. }\end{array}$ & $\begin{array}{l}\text { Investing in disaster } \\
\text { risk reduction for } \\
\text { resilience }\end{array}$ \\
\hline Priority 4 & $\begin{array}{l}\text { Reduce underlying risk } \\
\text { factors }\end{array}$ & $\begin{array}{l}\text { Enhancing disaster } \\
\text { preparedness for } \\
\text { effective response and } \\
\text { to "Build Back Better" } \\
\text { in recovery, } \\
\text { rehabilitation, and } \\
\text { reconstruction }\end{array}$ \\
\hline
\end{tabular}

Source: United Nations (2015); UNISDR (2005)

Insurance: Mechanisms need to be developed before a disaster strikes for raising precautionary funds or for sharing risks in order to provide relief, rehabilitation, and reconstruction efforts. The question is how much residual risk a government can manage itself - and how much residual risk it would need to share or transfer. Governments would need to maintain a pool of reserve funds to address small disasters, and would also need to subsidize insurance premiums, where necessary, for promoting private insurance products, such as index-based weather insurance for drought. Furthermore, beyond a certain level of risk, a government may have to share the indemnities with a private insurer, or the insurer may need to find a reinsurance company for risk-pooling through international markets. Further on, when a risk involves a major catastrophe, a government may have to transfer risk to capital markets through financial 
instruments such as catastrophe bonds. In such bonds, the issuer is liable to pay interest and principal if the event does not occur during the maturity period, and is not liable to pay back the principal if the event does occur.

It is also critical that special measures and mechanisms of insurance be designed for women, the poor, and marginalized groups. Until such mechanisms are developed, informal institutions like social networks and social capital, where extended families and communities help each other, may be the only forms of insurance available to communities within a reasonable amount of time after an event occurs. Furthermore, even after developing reasonable private insurance products, people may need to be 'nudged' to buy them because of the time inconsistency problem. For example, for drought protection, a farmer would need to decide now to purchase insurance and pay the premiums, but the payout, if any, would take place in the future, which tends to discourage farmers from enrolling in insurance programmes (Banerjee and Duflo 2011).

\subsubsection{Relating the Disaster Risk Reduction Elements to Programme Components}

In practice, decision makers and governments will ultimately determine if and how the separate elements of disaster risk reduction (information, infrastructure, institutions, and insurance) will be applied to help increase the strength and modalities of resilience to hazards. And that motivation, in turn, depends upon perceptions of risk-by individuals, by communities, by experts, and by society at large (Slovic 1987).

To account for these motivations and perceptions, resilience-building programmes should consider four strategies for changing human behaviour: (1) restrictions on choice through command-and-control mechanisms (e.g., zoning regulations, land use guidelines, and building codes); (2) monetary incentives (e.g., subsidies on insurance premiums); (3) persuasion by providing information (e.g., risk maps); and (4) 'nudging' (e.g., early warning systems). Often, a combination of these methods may be appropriate, and they will, of course, depend on the type of hazard event under consideration for resilience building. Table 11.10 provides some examples of these strategies.

\subsubsection{Resilience Building Programmes: Four Examples}

When we consider increasing resilience to disasters by reducing the vulnerability of communities through pursuing various measures, we should ask three questions, in this order:
- Whose resilience would we like to enhance? Individuals? Communities? Cities? Or larger units?

- What can be done to increase resilience pursuing one or more of the four disaster risk reduction elements: information, infrastructure, institutions, and insurance?

- How can individuals, communities, or city governments be motivated to adopt the measures that fall into one of these four disaster risk reduction elements?

Below we look at four examples of how these questions are answered using the $4 \times 4$ matrix in Table 11.10 of the four disaster risk reduction elements (information, infrastructure, institutions, and insurance) and four behavioural strategies (command-and-control, economic incentives, persuasion through information, and nudging).

\section{Index-based weather insurance}

Index-based weather insurance can improve drought resilience. Actions on five major fronts have been identified for such insurance:

a. invest in hydromet networks;

b. engage civil society organizations (CSOs) as social mobilizers to raise awareness;

c. invest in science to understand better the correlation of the index with actual crop yields;

d. invest in risk assessment; and

e. develop reinsurance markets.

In this case, the answer to the first two questions involves talking about increasing the resilience of the farmers using the insurance approach. On the third question, engaging CSOs as social mobilizers to raise awareness would be the persuasion strategy; subsidizing the insurance premium the farmer pays would be the incentives strategy; and offering help with maps to the location where insurance can be purchased would be a nudging strategy. Improving the uptake of crop insurance by farmers is often a real challenge and a combination of a number of strategies may be needed.

\section{Reviving drying springs}

Research suggests five different approaches for reviving dying springs:

a. identify recharge areas accurately;

b. prepare hydrogeological layout maps of the spring aquifer and recharge area;

c. build simple artificial recharge structures (e.g., trenches);

d. incentivize rainwater harvesting in farmers' fields; and

e. build local institutional arrangements to regulate demand. 
Table 11.10 Disaster risk reduction elements and behavioural change strategies

\begin{tabular}{|c|c|c|c|c|}
\hline & Information & Infrastructure & Institutions & Insurance \\
\hline $\begin{array}{l}\text { Command-and-control } \\
\text { mechanisms }\end{array}$ & $\begin{array}{l}\text { Zoning and } \\
\text { building code } \\
\text { enforcements }\end{array}$ & $\begin{array}{l}\text { - Infrastructure } \\
\text { development projects } \\
\text { - Technical design } \\
\text { standards } \\
\text { - Building codes } \\
\text { - Land use plan/zoning }\end{array}$ & $\begin{array}{l}\text { Institutionalization of } \\
\text { formal and informal } \\
\text { institutions }\end{array}$ & \\
\hline Incentives & & $\begin{array}{l}\text { - Rural housing } \\
\text { reconstruction } \\
\text { program (RHRP): } \\
\text { financial support for } \\
\text { seismic-resistant } \\
\text { housing } \\
\text { - Budget for } \\
\text { infrastructure } \\
\text { development }\end{array}$ & & $\begin{array}{l}\text { Subsidizing insurance premium } \\
\text { a farmer has to pay for } \\
\text { index-based weather insurance } \\
\text { for crops }\end{array}$ \\
\hline Persuasion & $\begin{array}{l}\text { Providing hazard } \\
\text { maps }\end{array}$ & $\begin{array}{l}\text { Technical guidelines } \\
\text { and dissemination } \\
\text { training by engineers } \\
\text { regarding infrastructure } \\
\text { development }\end{array}$ & $\begin{array}{l}\text { Support from formal and } \\
\text { informal institutions }\end{array}$ & $\begin{array}{l}\text { Engaging NGOs as social } \\
\text { mobilizers to raise awareness } \\
\text { of market insurance for crops }\end{array}$ \\
\hline Nudging & $\begin{array}{l}\text { Community-based } \\
\text { flood early } \\
\text { warning systems } \\
\text { (CBFEWS) }\end{array}$ & $\begin{array}{l}\text { Promoting retrofitting } \\
\text { with nudges to consider } \\
\text { traditional and cultural } \\
\text { preferences }\end{array}$ & $\begin{array}{l}\text { Institutional arrangement } \\
\text { for Community-based flood } \\
\text { early warning systems } \\
\text { (CBFEWS)Reviving } \\
\text { drying springs }\end{array}$ & $\begin{array}{l}\text { Encouraging self-insurance } \\
\text { through personal savings } \\
\text { motivated by a clearly visible } \\
\text { purpose such as loss of crops } \\
\text { due to floods }\end{array}$ \\
\hline
\end{tabular}

In the case of resilience, we are trying to bolster the capacity of farmers through information, infrastructure, and institutions. On the third question, building local institutional arrangements to regulate demand would be the command-and-control mechanism; grants or subsidized loans for building simple recharge structures such as trenches and ponds would be an incentive method; making the maps available would be persuasion by information; and incentivizing rainwater harvesting in farmers' fields would also be an incentive method, but may also require some nudging.

\section{Building resilience to flash floods}

A number of actions have been identified for building resilience to flash floods: hazard mapping, zoning policies, modern hydromet stations, information and communication technologies, local community involvement, and the national-local supportive interface. In this case, we are trying to build the resilience of the community through information, infrastructure, and institutions. On the third question, zoning policies would be the command-and-control mechanism; such policies would include road alignment and hydropower station location policies. Providing hazard maps would be persuasion and community-based flood early warning systems would be a nudge.

\section{Building resilience to earthquakes}

A number of actions identified for evidence-based analysis of water-related disasters may also be useful for identifying geophysical hazards, especially in the context of earthquakes that lead to landslides, dammed rivers, and flash floods subsequent to the breaching of landslide dams. The actions suggested for evidence-based disaster risk assessment are:

a. conduct risk assessment to identify the nature and magnitude of risk;

b. assess the effectiveness of preventive investment, land use planning, and emergency actions;

c. collect and archive hazard and damage data to develop indicators that make risk assessment evidence-based; and

d. apply the latest science and technology to promote practical risk assessment.

Developing and enforcing land use guidelines with the aim of limiting exposure to geohazards and paying more attention to areas where major infrastructure development projects such as roads and hydropower are proposed (Shrestha et al. 2016) would be a command-and-control mechanism. Similarly, developing applicable project design standards/building codes and communicating them to households and builders to enhance local government 
management for construction quality control in rural and urban areas (Molden et al. 2016; Shrestha et al. 2016) would be a combination of persuasion and command-and-control mechanisms. Both measures_zoning and building code enforcements-would also require nudges to motivate households and builders to follow the land use guidelines and building codes.

For pursuing these measures, evidence-based analysis could help to build a strong knowledge base. First, land use guidelines based on potential hazard maps could be updated with evidence-based hazard maps. Second, building codes based on potential hazards could be updated with the evidence of the damage to buildings during the earthquake. Evidence-based analysis may also help as a nudge for households occupying existing buildings, because they can see for themselves what could happen if the building codes are not followed.

In a typical case, especially because of the low-probability, high-impact nature of earthquakes, there may be a tendency for households to procrastinate and postpone retrofitting measures for a number of reasons. First, there may be some ambiguity about what constitutes optimal mitigation, because households cannot see what damage could occur if the retrofitting measures are not taken or the building codes not respected. Second, households may have budget constraints for investing in protective measures. In addition, they may see it as affordable or unaffordable based on how they frame it - an improvement similar to installing a leaky roof, which might ultimately lead a house to collapse, or an improvement similar to installing a leaky faucet, which might lead to high water bills. Third, they may also shy away from mitigation efforts because there is uncertainty as to when the next earthquake is likely to occur. It has been found that when making choices for the distant future, we may see the benefits clearly and decide on them, but when the time comes to pay, we tend to focus on costs-leading to procrastination. Therefore, nudges may be necessary to motivate households to invest in retrofitting measures and to sincerely respect building codes (Kunreuther and Michel-Kerjan 2008).

\subsubsection{Information Flows Are Crucial for Early Warning Systems}

Flood early warning systems are one of the most effective non-structural ways to minimize loss of life and property (Shrestha et al. 2008). Early warnings are transmitted from upstream to downstream communities to minimize the impacts of disasters. Accurate rainfall estimations and sharing of data and information are critical for reliable and timely flood forecasting and warnings. In many regions, operational flood forecasting has traditionally relied on a dense network of rain gauges or ground-based rainfall measuring radar equipment that report in real time. Rapid advances in communication technology are making access to data cheaper. At the same time, hydrological and meteorological monitoring and modelling technologies continue to improve significantly. These technological advances can be exploited to promote regional cooperation for flood risk reduction in the $\mathrm{HKH}$ by providing an end-to-end flood information system. The system functions as a decision support tool for decision makers to alert vulnerable communities in a timely and accurate manner.

In the HKH, ICIMOD in partnership with the World Meteorological Organization and the regional member countries of Bangladesh, Bhutan, China, India, Nepal, and Pakistan, has developed a regional flood information system (HKH HYCOS) that allows the visualization and extrapolation of real-time data from gauging stations to any geographical location providing information on the river water levels and the amount of rainfall (Shrestha et al. 2015). Using this real-time data, a flood outlook has been developed for the Ganges Brahmaputra basin. In August 2014, this flood outlook was used by Nepal's Department of Hydrology and Meteorology to issue a flood warning for the rivers of Nepal. It did so by means of a flood bulletin which was widely disseminated through its website (Shrestha and Pradhan 2015).

At the local level, the Hyogo Protocol and the SREX 2012 has identified a gap in getting flood early warnings directly to the communities that are most vulnerable. A community-based flood early warning system (CBFEWS) is an integrated system of tools and plans in which upstream communities, upon detecting flood risk, disseminate the information to vulnerable local communities downstream for preparedness and response to save lives and livelihoods (United Nations 2006). This is done using low-cost technology like wireless and solar-powered transmitters and receiver stations and mobile phone text messaging. Box 11.6 describes an example of this type of system in practice.

Box 11.6 Reaching the most vulnerable across the border

On 12 August 2017, local communities either side of the border crossed by the Ratu river-Bardibas in Mahottari district, Nepal and Bhittamore in Sitamarhi district, India - shared real-time information about an upcoming flood, which helped save lives and livelihoods in the vulnerable downstream communities in Bhittamore. The population in the Indo-Nepal border districts received information from the CBFEWS almost eight hours prior to the event. The upstream-downstream cross-border information flow provided an opportunity for the caretakers in the two 
countries, local communities, and partner organizations to know about the upcoming flood, prepare themselves and react immediately to save people and property (http://www.icimod.org/?q=28515).

CBFEWS was initiated by ICIMOD in early 2010 under a flash flood project. A human face was given to the technology in 2012 under the HICAP initiative, and CBFEWS was piloted in Assam, India. The impact of CBFEWS was acknowledged by UNFCCC's Momentum for Change 2014 Lighthouse Activity Award as a shining example innovative use of ICT. From 2015 onwards, CBFEWS was out scaled in India (Bihar) and Nepal under the Koshi Basin Initiative, in Pakistan under the Indus Basin Initiative, and in Afghanistan under a special project.

\subsubsection{Building Critical Infrastructure Which Is Resilient to Disasters}

Critical infrastructure is highly vulnerable to, and a major casualty of, natural disasters. Repairing or replacing infrastructure assets after a disaster is often difficult and costly, which can exacerbate the suffering of affected communities. The need to address climate risks in infrastructure projects is becoming increasingly urgent for economic development in emerging markets. The World Bank Group and other international financial institutions are well-placed to address the intersection of climate risks and infrastructure. They are screening investments for climate risks, providing analytical tools to measure risks, and designing measures to respond to risks, including innovative insurance approaches. The private sector can also contribute to disaster risk reduction through corporate social responsibility (CSR) activities. Sudmeier et al. (2013) developed an operational framework to measure resilience and vulnerability to disasters in the mid-hill regions of Nepal by defining resilience indicators based on a literature review, field observations, and a participatory approach with stakeholders. The framework can be used as a tool for guidance, providing direct interventions to reduce the risk of landslides and floods in the vulnerable mountainous regions of Nepal, including building critical infrastructure.

The HKH region is also physically vulnerable to earthquakes. Two major recent earthquakes in the region exemplify the urgent need to enhance physical resilience. On 8 October 2005, Pakistan's northern areas were struck by a 7.6 Mw earthquake. The impact of the 2005 Kashmir earthquake was devastating. More than 73,000 people were killed, 130,000 people were injured, and more than 200,000 houses
Table 11.11 Comparison of the Pakistan and Nepal earthquakes

\begin{tabular}{|c|c|c|}
\hline & $\begin{array}{l}2005 \text { Pakistan } \\
\text { earthquake }^{\mathrm{a}}\end{array}$ & $\begin{array}{l}2015 \text { Nepal } \\
\text { earthquake }^{b}\end{array}$ \\
\hline $\begin{array}{l}\text { Total damage and } \\
\text { loss }\end{array}$ & $\begin{array}{l}\text { USD 2,851 million } \\
\text { (PKR169,333 } \\
\text { million) }\end{array}$ & $\begin{array}{l}\text { USD 7,065 } \\
\text { million } \\
\text { (NPR 706,461 } \\
\text { million) }\end{array}$ \\
\hline $\begin{array}{l}\text { Housing damage } \\
\text { and loss }\end{array}$ & $\begin{array}{l}\text { USD } 1,152 \text { million } \\
(40.41 \%)\end{array}$ & $\begin{array}{l}\text { USD 3,505 } \\
\text { million } \\
(49.62 \%)\end{array}$ \\
\hline Deaths & 73,000 & 8,702 \\
\hline Injured & 70,000 & 22,303 \\
\hline Houses destroyed & 203,579 & 498,852 \\
\hline Houses damaged & 196,574 & 256,697 \\
\hline $\begin{array}{l}\text { Total recovery } \\
\text { needs } \\
\text { (USD million) }\end{array}$ & USD 3,503 million & $\begin{array}{l}\text { USD } 6,695 \\
\text { million }\end{array}$ \\
\hline $\begin{array}{l}\text { Housing recovery } \\
\text { needs } \\
\text { (US\$ million) }\end{array}$ & $\begin{array}{l}\text { USD } 1,552 \text { million } \\
(44.30 \%)\end{array}$ & $\begin{array}{l}\text { USD 3,278 } \\
\text { million } \\
(48.96 \%)\end{array}$ \\
\hline
\end{tabular}

Sources ${ }^{\mathrm{a}} \mathrm{ADB}$ and World Bank (2005); ${ }^{\mathrm{b}} \mathrm{NPC}(2015)$

were destroyed, rendering 3.5 million people homeless. In response, the Government of Pakistan collaborated with international partners to launch a Rural Housing Reconstruction Program (RHRP) at a cost of more than USD 1.5 billion (GFDRR 2013). RHRP relied on an owner-driven mechanism providing multi-tranche financial support to beneficiary households, based on inspection and certification at various stages of construction to ensure compliance with seismic-resistant standards (GFDRR 2013). On 25 April 2015, Nepal was struck by a 7.8 Mw earthquake which affected more than 8 million people. Table 11.11 summarizes the effects of the two earthquakes.

A comparison of the actions taken in the wake of the two earthquakes suggests that building resilience to earthquakes requires taking the following into account:

- Developing seismic-resistant structural designs should be the first important step in developing resilience, but this step needs to reflect on the common vulnerabilities in local practices, and identify the damage patterns and construction materials using damage assessments.

- Evidence-based persuasion and nudging are the keys to communicating the technical requirements to communities and inducing them to apply the designs on the ground.

- Another key factor in developing resilience is to have a transparent mechanism for cash disbursement and technical inspection. Dedicated authority to implement and enforce such standards will help provide a consistent and reliable agent for change in the community's behaviour. 


\subsubsection{The Role of Institutions Is Critical in Resilience Building Measures}

Building resilience to climate change, and its effectiveness, depend on how institutions (formal and informal) at the local and national level structure and internalize incentives for individual and collective action. The role of the institution is important if it is to support vulnerable social groups at the local level and can be considered as a specific component for enhancing capacity and delivering external resources to facilitate resilience and adaptation (Agrawal 2010; Christoplos et al. 2010; Dovers and Hezri 2010).

Pradhan et al. (2012) presented learning from four case studies in the $\mathrm{HKH}$ that analyse the role of policy and institutions in local adaptation planning to enhance community resilience. The building of effective resilience is determined by the interface between civic (civil society), public (state/government), and private (market/service organizations) institutions in their formal and informal roles operating at different scales. Agrawal (2010) emphasized that public sector institutions are more likely to facilitate adaptation strategies related to communal pooling, diversification, and storage owing to their command over authoritative action and their ability to channel technical and financial inputs to rural areas. Private sector organizations are more likely to have greater expertise in promoting market exchange and diversification, because of their access to financial resources. Non-profit service organizations may also be able to advance communal pooling. Civic sector institutions can strengthen different responses because of their greater flexibility in redefining goals and adopting new procedures. Depending on the extent to which there is a match or mismatch between the aims and comparative advantages of different institutions, the interface between institutions can be supportive or unsupportive.

A supportive interface is clearly desirable, but rarely found, where formal public institutions are supporting formal and informal institutions at all stages of adaptation planning. An example from China shows how a supportive interface can work. In 2005, after an extreme drought, the Ministry of Water Resources, National Reform and Development Commission, and the Ministry of Civil Affairs jointly issued a "Suggestion on strengthening the establishment of water users' associations" (Policy Decision 10), which recommended the establishment of water user associations to manage rural water infrastructure. The Baoshan Municipality Water Bureau established 520 water user associations between 2006 and February 2009, covering 142,449 households in 306 villages across 65 townships, and managing a total of 13,281 ha of irrigated land. All the counties in Baoshan issued their own implementation guidelines to establish the water user associations, with their own constitutions and regulations governing the operation of the associations. According to the government's report, a supportive interface was achieved between the policy implementation and water user associations, who owned and managed their water infrastructure, promoted water-saving practices, and reduced conflicts in the collection of fees in order to deal with drought. However, some water user associations experienced an unsupportive interface due to lack of funds for their operation, inefficient leadership, and lack of legal clarity regarding their status. The empirical evidence showed that the ability of the communities to maintain a supportive interface largely depended on the relationship between village leaders and local officials. This is an informal mechanism for obtaining a supportive interface from the public sector, which is a barrier to some communities that are not well positioned to procure the support they require from the local government.

In another example from Baoshan after the severe drought of March 2009, the Longyang District Government sent a "Notification on Strengthening Work against the Current Drought" to all government units mentioned in the Plan. The district agriculture bureau submitted a needs assessment and recovery report prepared in consultation with the communities in 18 townships. Based on the report, the provincial committee disbursed funds to those townships which had requested relief such as water pumping machines. The supportive interface between the provincial government and the communities was liaised by the district agriculture bureau to implement the government plan, which resulted in enhanced adaptive capacity and resilience of the communities to address drought.

These examples suggest that resilience building cannot occur in a social vacuum: It needs to be supported by institutions and policies. Planning for resilience building should give greater attention to the development of effective institutional arrangements, which requires supportive interfaces between institutions for building adaptive capacity and enhancing the resilience of communities (Pradhan et al. 2012).

\subsubsection{Nudging Could Help Motivate People for Self-insurance}

In industrialized countries, market insurance is the primary means of risk management. In the HKH, governments and the private sector are currently trying to promote market insurance for various uses, for example crop insurance. Until market insurance becomes more widely adopted in the region, self-insurance products could be used to help increase resilience to natural disasters. Self-insurance in this context is defined as having adequate personal resources to cope with 
the consequences of a disaster. Reports suggest that it is easier to motivate people to save when the purpose of saving is clearly visible (Soman and Cheema 2011). This implies that it would be easier to motivate individuals to purchase self-insurance if they live in areas prone to floods and landslides, which occur more frequently (Tversky and Kahneman 1974), than if they live in areas prone to earthquakes and droughts, which occur less frequently. Financial products and institutional mechanisms for saving also need to be simple and practical, including those for small savings by the marginalized and the poor (Dupas and Robinson 2013).

Two field experiments conducted to motivate individuals to save, provide some useful lessons for savings for natural hazards. These experiments are noteworthy because they demonstrate how nudging by developing the appropriate choice architecture could help motivate people to save for self-insurance.

Soman and Cheema (2011) in India demonstrated the importance of clear objectives for which individuals are saving - 'earmarking' money in the sense of reserving or setting it aside for a particular purpose. The researchers tested whether households of infrastructure construction workers (146 daily-wage labourers) whose earmarked money envelope was labelled with their children's pictures would save more than participants whose earmarked envelope was not labelled in this way. Regardless of whether the target savings were set at high (INR 80) or low (INR 40), the household savings over 14-weeks were higher for those with a money envelope earmarked with their children's pictures.

Dupas and Robinson (2013) in Kenya demonstrated the importance of a storage mechanism, earmarking, and social commitment in the process of saving for preventative health activities and health emergencies. The study involved participants in 113 local rotating savings and credit associations (ROSCA), in which participants meet periodically and contribute equal amounts to a pot that is taken by one of them. The participants were encouraged to save for health and divided into five groups: two for preventative health with nudging, one for health emergencies only with nudging, one for both preventative and emergency health with nudging, and one without nudging (the savings device). They found that for preventative health, the average impact of earmarking was KES 57.54 and that of social commitment KES 273.46. For health emergencies, they estimated the percentage of participants who could not afford medical treatment for an illness in the past three months but could afford it after participating in the earmarking process. The average impact of the earmarking process was $8 \%$ when not monitored and $12 \%$ when monitored.

These experiments suggest that a simple savings device, such as an envelope or a storage box, may help to nudge people to save. The savings can be increased by mentally clarifying the purpose of the savings, and further increased by normative pressure through social commitment. In the disaster risk reduction literature, Kunreuther and Michel-Kerjan (2008: p. 60) argue that "recent disasters have provided empirical evidence that a large number of people do nothing in advance of a disaster because they use budgeting heuristics, misperceive the risk, underweigh the future and/or are myopic, fail to learn from past experience, and are influenced by social norms and interdependencies". Two of these issues are addressed in the experiments: (1) earmarking, monitored and unmonitored, to take care of budgeting heuristics by clarifying the purpose of saving; and (2) normative pressures on savers through social commitment, to take care of social norms and interdependencies. Although the experiments were not directly related to saving to cope with natural hazards, they provide important lessons for encouraging self-insurance through savings for vulnerable populations.

\subsection{Summary and Way Forward}

Mountain communities are threatened by numerous risks from natural hazards and a changing risk pattern. Disaster risk reduction is particularly important in mountain areas for many reasons, including the multi-hazard environment, land use pressure, and the effects of climate change. Flash floods and landslides are the most frequently occurring natural hazards in middle hill terrain in the HKH, particularly during the monsoon season, and flooding in the plains. There is an increasing trend in the number of events reported, people killed, and economic loss due to natural disasters in the region. Records of natural disasters and related studies indicate that more women than men die when disasters strike. This is the result of women's lack of information, mobility, decision-making power, and access to resources and training, as well as gender-based sociocultural norms and barriers, conventional gender responsibilities, and high rates of male outmigration.

Assessing risk without considering the effects of climate change is no longer an option in the mountainous areas, which are particularly sensitive to climate change. Risk-informed planning will help to create safer land use practices and hazard-proof infrastructure and housing. In addition, cross-border cooperation to share information and best practices is necessary for early warning systems and other precautionary measures. Access is important in effective response. Mountain communities are more vulnerable as a result of their remoteness, poor accessibility, and lack of emergency communication. Thus, sustainable mountain development requires a systematic and integrated risk management approach to avoid or reduce future losses.

Disaster risk is expressed as the probability of loss of life, injury, or destroyed or damaged assets which could occur to a system, society, or community in a specific period of time. 
Such probability can be estimated by assessing hazards, exposure, and vulnerability. While hazards and exposure can be estimated empirically and quantitatively using historical events, vulnerability assessment has multiple disciplinary theories. Although it is not easy to assess the physical vulnerability in the HKH quantitatively based on data, estimation is possible using national data, such as data on quality of infrastructure services from the World Economic Forum, as proxies. Socioeconomic vulnerability assessments should take into account multiple dimensions, such as income inequality, gender inequality, governance, and national progress for disaster risk reduction in the light of the Sendai Disaster Risk Reduction Framework.

Enhancing community resilience to hazards by reducing vulnerability and pursuing resilience-building measures needs a clear understanding of disaster risks, which can help policy makers to prioritize strategies that increase their population's resilience to these events. A framework is needed for assessing risks due to hazard events and suggesting measures to increase resilience of the communities in the HKH. The framework proposed draws upon the principles of the 1994 Yokohama Strategy and Plan of Action, the 2005 Hyogo Framework of Action, the Sendai Framework for Disaster Risk Reduction 2015-2030, and UNDP's 2007 Human Development Report. It envisions a $4 \times 4$ matrix emphasizing the four elements of disaster risk reduction - information, infrastructure, institutions, and insurance-against the four elements for successful planning and executioncommand-and-control mechanisms (e.g., zoning regulations; land use guidelines and building codes); monetary incentives (e.g., subsidies on insurance premiums); persuasion by providing information (e.g., risk maps); and nudging (e.g., early warning systems). The framework also helps to address three key questions for pursuing resilience-building measures: Whose resilience would we like to enhance? What can be done to increase resilience? How can the individuals, communities, or city governments be motivated to adopt the measures that fall into one of these four categories? Ultimately, the individual or the group of beneficiaries whose resilience we are trying to enhance must select one or more of these methods to increase resilience. Often, a combination of methods may be appropriate; this will depend on the type of hazard event under consideration for resilience building.

\section{References}

ADB. (2013a). Asian water development outlook 2013: Managing water security in Asia and the Pacific. Mandaluyong City, Philippines: Asian Development Bank.

ADB. (2013b). The rise of natural disasters in the Asia and the Pacific. Mandaluyong City, Philippines: Asian Development Bank. https:// www.adb.org/sites/default/files/evaluation-document/36114/files/ rise-natural-disasters-asia-pacific.pdf.
ADB and World Bank. (2005). Pakistan 2005 Earthquake Preliminary Damage and Needs Assessment. http://www.recoveryplatform.org/ assets/publication/PDNA/CountryPDNAs/Pakistan_Earthquake_ 2005_Preliminary\%20Damage\%20and\%20Needs\%20Assessment. pdf.

Adger, W. N., \& Kelly, P. M. (1999). Social vulnerability to climate change and the architecture of entitlements. Mitigation and Adaptation Strategies for Global Change, 4(3-4), 253-266.

Agrawal, A. (2010). Local institutions and adaptation to climate change. In R. Mearns \& A. Norton (Eds.), social dimensions of climate change: Equity and vulnerability in a warming world (pp. 173-198). Washington DC, USA: The World Bank.

Aguilar, L., Granat, M., \& Owren, C. (2015). Roots for the future: The Landscape and way forward on gender and climate change. Washington, DC: IUCN \& GGCA.

Ahmad, S., Hussain, Z., Qureshi, A. S., Majeed, R., \& Saleem, M. (2004). Drought Mitigation in Pakistan: Current Status and Options for Future Strategies. Working paper 85. Colombo: Sri Lanka. International Water Management Institute.

Alkire, S., \& Robles, G. (2017). Multidimensional Poverty Index Summer 2017: Brief methodological note and results. OPHI Methodological Note 44, University of Oxford.

Allen, S. K., Rastner, I. P., Arora, I. M., Huggel, I. C., \& Stoffel, I. M. (2015). Lake outburst and debris flow disaster at Kedarnath, June 2013: Hydrometeorological triggering and topographic predisposition Landslides https://doi.org/10.1007/s10346-0150584-3.

Ariabandhu, M. M. (2009). Sex, gender and gender relations in disasters. In E. Enarson \& G. P. D. Chakrabarti (Eds.), Women, gender and disaster: Global issues and initiatives.

Ariyabandu, M., \& Wickramasinghe, M. (2003). Gender dimensions in disaster management: A guide for South Asia. Practical Action.

Armijo, R., Tapponnier, P., \& Han, T. (1989). Late Cenozoic right-lateral strike-slip faulting in southern Tibet. Journal of Geophysical Research: Solid Earth, 94(B3), 2787-2838.

Avouac, J., \& Tapponnier, P. (1993). Kinematic model of active deformation in central Asia. Geophysical Research Letters, 20(10), 895-898.

Awasthi, I. C., Mehta, G. S., \& Mamgain, R. P. (2014). Uttarakhand disaster: Lessons and way forward, Occasional-6, Gri Institute of Development Studies. Lucknow, India.

Banerjee, A., \& Duflo, E. (2011). Poor economics: Rethinking poverty and the ways to end it. Noida, U.P., India: Random House India.

Bergstrand, K., Mayer, B., Brumback, B., \& Zhang, Y. (2015, June). Assessing the Relationship between social vulnerability and community resilience to hazards. Social Indicators Research, 122(2), 391-409. https://doi.org/10.1007/s11205-014-0698-3.

Bhatia, et al. (2000). A probabilistic hazard map of India and adjoining region, Global Seismic Hazard Program. http://www.seismo.ethz. $\mathrm{ch} / \mathrm{GSHAP} /$.

Bilham, R., Larson, K., \& Freymueller, J. (1997). GPS measurements of present day convergence across the Nepal Himalaya. Nature, 386, 61-64. https://doi.org/10.1038/386061a0.

Bilham, R., Gaur, V. K., \& Molnar, P. (2001). Himalayan seismic hazard. Science, 293, 1442-1444. https://doi.org/10.1126/science. 1062584.

Birkmann, J., Cardona, O. D., Carreño, M. L., Barbat, A. H., Pelling, M., Schneiderbauer, S., et al. (2013). Framing vulnerability, risk and societal responses: The MOVE framework. Natural Hazards, 67(2), 193-211. https://doi.org/10.1007/s11069-013-0558-5.

Blaikie, P., Cannon, T., Davis, I., \& Wisner, B. (1994). At risk: Natural hazards, people's vulnerability and disasters. Routledge.

Blumstein, S., Pohl, B., \& Tänzler, D. (2016). Water and climate diplomacy: Integrative approaches for adaptive action in transboundary river basins. Germany: Adelphi, Berlin. 
Bollinger, L., Avouac, J. P., Cattin, R., \& Pandey, M. R. (2004). Stress build up in the Himalaya. Journal Geophysical Research, 109, B11405.

Brooks, N., \& Adger, W. N. (2005). The determinants of vulnerability and adaptive capacity at the national level and the implications for adaptation. In W. N. Adger, N. Arnell, \& E. L. Tompkins (Eds.), Global environmental change part A (vol. 15, pp. 151-162).

Carr, E. R., Abrahams, D., De la Poterie, A. T., Suarez, P., \& Koelle, B. (2015). Vulnerability assessments, identity and spatial scale challenges in disaster-risk reduction. Jàmbá: Journal of Disaster Risk Studies, 7, 1-17. https://doi.org/10.4102/jamba.v7i1.201.

Champati Ray, P. K., Chattoraj, S. L., Bisht, M. P. S., et al. (2016). Natural Hazards, 81, 227. https://doi.org/10.1007/s11069-0152076-0.

Chenoweth, J. L., \& Feitelson, E. (2001). Analysis of factors influencing data and information exchange in international river basins. Water International, 26(4), 499-512. https://doi.org/10. 1080/02508060108686951.

Christoplos, I., Rodriguez, T., Schipper, E. L. F., Narvaez, E. A., Mejia, K. M. B., Buitrago, R., et al. (2010). Learning from recovery after hurricane Mitch. Disasters, 34(2), S202-S219.

Ciurean, R. L., Schroter, D., \& Glade, T. (2013). Conceptual frameworks of vulnerability assessments for natural disasters reduction. In Approaches to disaster management-Examining the implications of hazards, emergencies and disasters (pp. 3-32). https://doi.org/10.5772/55538.

CRED and UNISDR. (2016). The Human Cost of Weather-Related Disasters 1995-2015.

Donner, W., \& Rodríguez, H. (2011). Disaster Risk and Vulnerability: The Role and Impact of Population and SocietyEm-DAT (2016). Em-DAT: The international disaster database. Centre for Research on the Epidemiology of Disasters. Universite Catholique de Louvain. Brussels. Retrieved July, 2016, from www.emdat.be.

Dankers, R., Arnell, N. W., Clark, D. B., Falloon, P. D., Fekete, B. M., Gosling, S. N., et al. (2014). First look at changes in flood hazard in the Inter-Sectoral Impact Model Intercomparison Project ensemble. PNAS, 111(9), 3257-3261.

de Mets, C., Gordon, R. G., Argus, D. F., \& Stein, S. (1994). Effect of recent revisions to the geomagnetic reversal time scale on estimates of current plate motions. Geophysical Research Letters.

Dovers, S. R., \& Hezri, A. A. (2010). Institutions and policy processes: The means to the ends of adaptation.

Dow, K. (1992). Exploring differences in our common future(s): The meaning of vulnerability to global environmental change. Geoforum, 23, 417-436.

Dunning, S., Rosser, N., Petley, D., \& Massey, C. (2006). Formation and failure of the Tsatichhu landslide dam, Bhutan. Landslides, 3 (2), 107-113.

Dupas, P., \& Robinson, J. (2013). Why don't the poor save more? Evidence from health savings experiments. The American Economic Review, 103(4), 1138-1171.

Elalem, S., \& Pal, I. (2015). Mapping the vulnerability hotspots over Hindu-Kush Himalaya region to flooding disasters. Weather and Climate Extremes, 8, 46e58. http://dx.doi.org/10.1016/j.wace.2014. 12.001 .

FFC (Federal Flood Commission). (2010). Annual flood report. Islamabad: Ministry of Water and Power, Government of Pakistan.

Gaire, S., Castro Delgado, R., \& Arcos González, P. (2015). Disaster risk profile and existing legal framework of Nepal: Floods and landslides. Risk Management and Healthcare Policy, 8, 139-149.

Garschagen, M., Hagenlocher, M., Comes, M., Dubbert, M., Sabelfeld, R., Lee, Y. J., et al. (2016). World Risk Report 2016. World Risk Report. Bündnis Entwicklung Hilft and UNU-EHS. http:// weltrisikobericht.de/wp-content/uploads/2016/08/

WorldRiskReport2016.pdf.
Gentle, P., \& Maraseni, T. N. (2012). Climate change, poverty and livelihoods: Adaptation practices by rural mountain communities in Nepal. Environmental Science \& Policy, 21, 24-34. https://doi.org/ 10.1016/j.envsci.2012.03.007.

Gerlak, A., Lautze, J., \& Giordana, M. (2010). Water resources data and information exchange in transboundary water treaties. International Environmental Agreements, 11(2), 179-199.

GFDRR. (2012). Disaster risk management in South Asia: A regional overview. In Global facility for disaster reduction and recovery. The World Bank: Washington DC.

GFDRR. (2013). Learning from the Pakistan experience of post-2005 Earthquake rural housing reconstruction. Project Highlights. Issue No 7. The World Bank: Washington DC.

Gill, J. C., \& Malamud, B. D. (2016). Hazard interactions and interaction networks (cascades) within multi-hazard methodologies. Earth System Dynamics, 7(3), 659-679.

Goswami, B. N., Venugopal, V., Sengupta, D., Madhusoodanan, M. S., \& Xavier, P. K. (2006). Increasing trend of extreme rain events over India in a warming environment. Science, 314, 1442-1445.

Grossman, M. (2006). Cooperation on Africa's international waterbodies: Information needs and the role of information-sharing. In W. Scheumann \& S. Neubert (Eds.), Transboundary water management in Africa: Challenges for development cooperation (pp. 173235). Bonn, Germany: German Development Institute.

Guha-Sapir, D., Hoyois, Ph, \& Below, R. (2014). Annual disaster statistical review 2013: The numbers and trends. Brussels: CRED.

Gupta, V., Nautiyal, H., Kumar, V., Jamir, I., \& Tandon, R. S. (2016). Landslide hazards around Uttarkashi township, Garhwal Himalaya, after the tragic flash flood in June 2013. Natural Hazards, 80(3), 1689-1707. https://doi.org/10.1007/s11069-015-2048-4.

Gupta, S. K., \& Chalisgoankar, R. (1999). Blockade of River Mandakini in Uttar Pradesh-hazard assessment by mathematical approach. Journal of Indian Water Resources Society, 19(5)(1), 14-18.

Gurung, D. R., Khanal, N. R., Bajracharya, S. R., Tsering, K., Joshi, S., Tshering, P., et al. (2017). Lemthang Tsho Glacial Lake Outburst Flood (GLOF) in Bhutan: Cause and impact. Geoenvironmental Disaster (accepted).

Haeberli, W., Buetler, M., Huggel, C., Lehmann Friedli, Th, Schaub, Y., \& Schleiss, A. J. (2016). New lakes in deglaciating high-mountain regions - Opportunities and risks. Climatic Change, 139(2), 201-214. https://doi.org/10.1007/s10584-016-1771-5.

Hewitt, K., \& Liu, J. (2010). Ice-dammed lakes and outburst floods, Karakoram Himalaya: Historical perspectives on emerging threats. Physical Geography, 31(6), 528-551; Singh, J., Park, W-K., \& Yadav, R. (2006). Tree-ring based hydrological records for western Himalaya, India, since A.D. 1560. Climate Dynamics, 26, 295-303; Yadav, R., \& Singh, J. (2002). Tree-ring-based spring temperature patterns over the past four centuries in Western Himalaya. Quaternary Research, 57, 299-305.

Higaki, D., \& Sato, G. (2012). Erosion and sedimentation caused by glacial lake outburst floods in the Nepal and Bhutan Himalayas. Global Environmental Research, 16, 71-76 (English Edition).

ICIMOD. (2016). Consultation workshop on landslide inventory, risk assessment, and mitigation in Nepal. In ICIMOD. Proceedings 2016/2. Kathmandu: ICIMOD.

Immerzeel, W. W., Beek, L. P. H. V., \& Bierkens, M. F. P. (2010). Climate change will affect the Asian water towers. Science, 328 (5984), 4. https://doi.org/10.1126/science.1183188.

IPCC. (2012). Summary for policymakers. In C. B. Field, V. Barros, T. F. Stocker, D. Qin, D. J. Dokken, K. L. Ebi, M. D. Mastrandrea, K. J. Mach, G.-K. Plattner, S. K. Allen, M. Tignor, \& P. M. Midgley (Eds.), Managing the risks of extreme events and disasters to advance climate change adaptation (pp. 3-21). A Special Report of Working Groups I and II of the Intergovernmental Panel on Climate Change. Cambridge University Press, Cambridge, UK, and New York, NY, USA. 
Islam, A. S., Haque, A., \& Bala, S. K. (2010). Hydrologic characteristics of floods in Ganges-Brahmaputra-Meghna (GBM) delta. Natural Hazards, 54, 797. https://doi.org/10.1007/s11069-0109504-y.

ISDR and UNEP. (2007). Environment and Vulnerability: Emerging Perspectives.

Ives, J. D., Shrestha, R. B., Mool, P. K., et al. (2010). Formation of glacial lakes in the Hindu Kush-Himalayas and GLOF risk assessment. Kathmandu, Nepal: ICIMOD.

Jodha, N. S. (1992). Mountain perspective and sustainability: A framework for development strategies. In N. S. Jodha, M. Banskota, \& T. Partap (Eds.), Sustainable mountain agriculture (Vol. 1, pp. 41-82), Perspectives and issues. New Delhi: Oxford and IBH Publishers.

Jodha, N. S. (1997). Mountain agriculture. In B. Messerli \& J. D. Ives (Eds.), Mountains of the world: A global priority. New York: The Parthenon Publishing Group.

Joseph, S., Sahai, A. K., Sharmila, S., Abhilash, S., Borah, N., Chattopadhyay, R., et al. (2013). North Indian heavy rainfall event during June 2013: Diagnostics and extended range prediction. Climate Dynamics. https://doi.org/10.1007/s00382-014-2291-5.

Kargel, J. S., Leonard, G. J., Shugar, D. H., Haritashya, U. K., Bevington, A., Fielding, E. J., et al. (2016). Geomorphic and geologic controls of geohazards induced by Nepal's 2015 Gorkha earthquake. Science, 351(6269). https://doi.org/10.1126/science. aac8353. http://science.sciencemag.org/content/351/6269/aac8353.

Khan, A. N., \& Khan, S. N. (2015). Landslide risk and reduction approaches in Pakistan. In A.-U. Rahman, N. A. Khan, \& R. Shaw (Eds.), Disaster risk reduction approaches in Pakistan (pp. 145160). Springer Japan: Tokyo.

Khanal, N. R., Shrestha, M., \& Ghimire, M. L. (2007). Preparing for flood disaster: Mapping and assessing in the Ratu watershed. Kathmandu: ICIMOD.

Kunreuther, H. C., \& Michel-Kerjan, E. O. (2008). A framework for reducing vulnerability to natural disasters: Ex ante and ex post Considerations. Commissioned by the Joint World Bank- UN project on the Economics of Disaster Risk Reduction. Wharton Risk Management and Decision Processes Center. The Wharton School, University of Pennsylvania, Philadelphia, Pennsylvania, USA.

Lotay, Y. (2015). Country Report: BhutanRep., 20 pp.

Lavell, A., Oppenheimer, M., Diop, C., Hess, J., Lempert, R., Li, J., et al. (2012). Climate change: New dimensions in disaster risk, exposure, vulnerability, and resilience. In C. B. Field, V. Barros, T. F. Stocker, D. Qin, D. J. Dokken, K. L. Ebi, M. D. Mastrandrea, K. J. Mach, G.-K. Plattner, S. K. Allen, M. Tignor, \& P. M. Midgley (Eds.), Managing the risks of extreme events and disasters to advance climate change adaptation (pp. 25-64). A Special Report of Working Groups I and II of the Intergovernmental Panel on Climate Change (IPCC). Cambridge University Press, Cambridge, UK, and New York, NY, USA.

Leduc, B. (2011). Mainstreaming gender in mountain development: From policy to practice, lessons learned from a gender assessment of four projects implemented in the Hindu Kush-Himalayas. Kathmandu, Nepal: ICIMOD.

Macchi, M., Gurung, A. M., Hoermann, B., \& Choudhury, D. (2011). Climate variability and change in the Himalayas: Community perceptions and responses. Kathmandu, Nepal: International Centre for Integrated Mountain Development (ICIMOD).

Maplecroft. (2011). Climate change vulnerability index 2011. https:// maplecroft.com/about/news/ccvi.html.

Mehta, M. (2007). Gender matters. Kathmandu: ICIMOD.

Molden, D., Sharma, E., \& Acharya, G. (2016). Lessons from Nepal's Gorkha earthquake 2015. In S. P. Singh, S. C. Khanal, \& M. Joshi (Eds.), Lessons from Nepal's earthquake for the Indian Himalayas and the Gangetic plains (pp 1-14). Nainital, Uttarakhand, India: Central Himalayan Environment Association.

MoSWRR. (2009). Myanmar Action Plan on Disaster Risk Reduction (MAPDRR) Rep.

MoPE. (2017). Vulnerability and Risk Assessment Framework and Indicators for National Adaptation Plan (NAP) Formulation Process in Nepal. Ministry of Population and Environment (MoPE), Kathmandu.

Nadim, F., Kjekstad, O., Peduzzi, P., Herold, C., \& Jaedicke, C. (2006). Global landslide and avalanche hotspots. Landslides: Journal of the International Consortium on Landslides, 3(2), 159-173.

Nadim, F., Jaedicke, C., Smebye, H., \& Kalsnes, B. (2013). Assessment of global landslide hazard hotspots. In K. Sassa, B. Rouhban, S. Briceño, M. McSaveney, \& B. He (Eds.), Landslides: global risk preparedness. Heidelberg: Springer, Berlin.

Nellemann, C., Verma, R., \& Hislop, L. (2011). Women at the frontline of climate change-Gender risks and hopes: A rapid response assessment. Arendal, Norway: United Nations Environment Programme (UNEP), GRID.

NPC (Nepal Planning Commission). (2015). Nepal Earthquake 2015: Post Disaster Needs Assessment 1 Vol. B: Sector reports. Government of Nepal.

Nibanupudi, H. K., \& Khadka, M. (2015) Gender and disaster resilience in the Hindu Kush Himalayan region. In R. Shaw \& H. K. Nibanupudi (Eds.), Mountain hazards and disaster risk reduction (pp. 233-250). Springer Japan.

Nogués-Bravoa, D., Araújoc, M. B., Erread, M. P., \& Martínez-Rica, J. P. (2007). Exposure of global mountain systems to climate warming during the 21st Century. Global Environmental Change, $17,420-428$.

O'Brien, K. L., \& Leichenko, R. L. (2000). Double exposure: Assessing the impacts of climate change within the context of economic globalization. Global Environmental Change, 10, 221232.

Oxley, M. C. (2013). Editorial: A "people-centered principles-based" post-Hyogo framework to strengthen the resilience of nations and communities. International Journal of Disaster Risk Reduction, 4, $1-9$

Pescaroli, G., \& Alexander, D. (2015). A definition of cascading disasters and cascading effects: Going beyond the "toppling dominos" metaphor. Planet@ Risk, 3(1).

Pradhan, N. S., Khadgi, V. R., Schipper, L., Kaur, N., \& Geoghegan, T. (2012). Role of policy and institutions in local adaptation to climate change. Kathmandu, Nepal: ICIMOD.

Pusch, C. (2004). Preventable losses: Saving lives and property through hazard and risk management-A comprehensive risk management framework for Europe and Central Asia. Disaster Risk Management Working Paper 9. World Bank. Washington DC.

Rai, B. (2004). Himalayan seismicity and probability of future earthquake. IAGA $W G, 1,20$.

Rasul, G., Sharma, B., Mishra, B., Neupane, N., Dorji, T., Khadka, M., et al. (2015). Strategic framework for resilient livelihoods in earthquake-affected areas of Nepal. ICIMOD Working Paper 2015/6. Kathmandu: ICIMOD.

Richardson, S. D., \& Reynolds, J. M. (2000). An overview of glacial hazards in the Himalayas. Quaternary International, 65-66, 31-47.

Rautela, P. (2013). Lessons learnt from the deluge of Kedarnath, Uttarakhand, India. Asian Journal of Environment and Disaster Management, 5(2), 43-51.

SAARC. (2010). SAARC Workshop on Landslide Risk Management in South Asia, edited (p. 126).

Sarwar, G. M. (2008, November 2008). Landslide Tragedy of Bangladesh, The First World Landslide Forum, 18-21 Nov 2008, United Nations University (UNU), Tokyo, Japan. 
Schipper, E. (2009). Meeting at the crossroads?: Exploring the linkages between climate change adaptation and disaster risk reduction. Climate and Development, 1(1), 16-30.

Schwanghart, W., Worni, R., Huggel, C., Stoffel, M., \& Korup, O. (2016). Uncertainty in the Himalayan energy-water nexus: Estimating regional exposure to glacial lake outburst floods. Environmental Research Letters, 11, 074005. https://doi.org/10.1088/17489326/11/7/074005.

SDMC. (2008). South Asian Disaster Report 2007. New Delhi, India: SAARC Disaster Management Centre.

SDMC. (2011). SAARC Expert Group Meeting on Landslide Terminology, Classifications, Documentation and Hazard Mapping. SAARC Disaster Management Center, New Delhi, India.

Shaw, R., \& Nibanupudi, H. K. (2015). Overview of Mountain Hazards Issues. In Mountain hazards and disaster risk reduction (pp. 1-11). Springer Japan.

Shrestha, A. B., Bajracharya, S. R., Kargel, J. S., \& Khanal, N. R. (2016). The impact of Nepal's 2015 Gorkha earthquake-induced geohazards. ICIMOD Research Report 2016/1. Kathmandu, ICIMOD.

Shrestha, A. B. (2008a). Resource manual on flash flood risk management: Module 2 Non-structural Measures. Kathmandu: ICIMOD.

Shrestha, M. S. (2008b) Impacts of floods in South Asia. Journal of South Asia Disaster Studies, 1(1), 85-106 (SAARC Disaster Management Centre, New Delhi, India).

Shrestha, A. B., \& Pradhan, N. S. (2015). Strengthening flash flood risk management in the Hindu Kush Himalayas. In Case studies presented during the INR 1.3 AP session on Climate change adaptation and mitigation in Africa, Americas, Asia-Pacific, Europe and the Mediterranean region/Building resilience to water-related disasters in the Asia-Pacific region of the 7th World Water Forum. Kathmandu, Nepal: ICIMOD.

Shrestha, A. B., Shah, S. H., \& Karim, R. (2008). Resource manual on flash flood risk management: Community-based management. Kathmandu, Nepal: ICIMOD.

Shrestha, M. S., \& Chhophel, K. (2010). Disasters in the Himalayan Region: A case of Tsatichu Lake in Bhutan. In Behiem, et al. (Eds.), Integrated watershed management: Perspective and problems, Einar (pp. 211-222). New York: Springer.

Shrestha, M. S, Kafle, S., Gurung, M., Nibanupudi, H. K., Khadgi, V. R., \& Rajkarnikar, G. (2014). Flood early warning systems in Nepal: A gendered perspective. ICIMOD Working Paper 2014/4. Kathmandu: ICIMOD.

Shrestha, M. S., Grabs, W. E., \& Khadgi, V. R. (2015). Establishment of a regional flood information system in the Hindu Kush Himalayas: Challenges and opportunities. International Journal of Water Resources Development, 31(2), 238-252. https://doi.org/10. 1080/07900627.2015.1023891.

Sietz, D. (2014). Regionalisation of global insights into dryland vulnerability: Better reflecting smallholders' vulnerability in Northeast Brazil. Global Environmental Change, 25(1), 173-185. https:// doi.org/10.1016/j.gloenvcha.2014.01.010.

Sietz, D., Ordonez, J. C., Kok, M. T. J., Janssen, P., Hilderink, H. B. M., Tittonell, P., et al. (2017). Nested archetypes of vulnerability in African drylands: Where lies potential for sustainable agricultural intensification? Environmental Research Letters, 12(9), 95006. Retrieved from http://stacks.iop.org/1748-9326/12/i=9/a=095006.

Singh, J., Park, W.-K., \& Yadav, R. (2006). Tree-ring based hydrological records for western Himalaya, India, since A.D. 1560. Climate Dynamics, 26, 295-303.

Slovic, P. (1987). Perception of risk. Science, 236, 280-285.

Slovic, P. (1999, August). Trust, emotion, sex, politics, and science: Surveying the risk-assessment battlefield. Risk Analysis, 19(4), 689-701.
Soman, D., \& Cheema, A. (2011). Earmarking and partitioning: Increasing saving by low-income households. Journal of Marketing Research, XLVIII(Special Issue), S14-S22).

Sonesson, M., \& Messerli, B. (Eds.). (2002). The Abisko agenda: Research for mountain area development, Ambio special report 11. Stockholm: Royal Swedish Academy of Sciences.

Stark, C., Daniel Petz, D., \& Ferris, E. (2013). Disaster risk management: A Gender-sensitive approach is a smart approach (Chapter 4). In The year of recurring disasters: A review of natural disasters in 2012.

Sudmeier, K. I., Jaboyedoff, M., \& Jaquet, S. (2013). Operationalizing "resilience" for disaster risk reduction in mountainous Nepal. Disaster Prevention and Management, 22(4), 366-377.

Sundriyal, Y. P., Shukla, A. D., Rana, N, Jayangondaperumal, R., Srivastava, P., Chamyal, L. S., et al. (2015). Terrain response to the extreme rainfall event of June 2013: Evidence from the Alaknanda and Mandakini River Valleys, Garhwal Himalaya, India. Episodes, 38(3), $11 \mathrm{pp}$.

Tanner, T. (2003). Peopling mountain environments: Changing Andean livelihoods in northwest Argentina. Geographical Journal, 169, 205-214.

Tariq, M. A. U. R., \& Giesen, N. V. D. (2011). Floods and Flood Management in Pakistan. Physics and Chemistry of the Earth. https://doi.org/10.1016/j.pce.2011.08.014.

Tse-ring, K., Sharma, E., Chettri, N., \& Shrestha, A. (Eds.). (2010). Climate change vulnerability of mountain ecosystems in the eastern Himalayas-Synthesis report. Kathmandu, Nepal: ICIMOD.

Tversky, A., \& Kahneman, D. (1974). Judgment under uncertainty: Heuristics and biases. Biases in judgments reveal some heuristics of thinking under uncertainty. Science, 185, 1124-1131. https://doi. org/Cited By (since 1996) 3914\nExport Date 30 November 2011.

Twigg, J. (2009). Characteristics of a disaster-resilient community: A guidance note. London, UK: Department for International Development (DFID).

UNDP (United Nations Development Programme). (2007). Human development report 2007/2008, fighting climate change: Human solidarity in a divided world. New York, NY: Palgrave Macmillan.

UNDP. (2016). United Nations Development Programme, Human Development Index. http://hdr.undp.org/en/content/humandevelopment-index-hdi.

UNEP. (1997). Asian disaster management news: Gender and disaster. A Newsletter of the Disaster Management Community in Asia and the Pacific, 3(3). Nairobi, Kenya: UNEP.

UNISDR. (2005, January 18-22). Hyogo Framework of Action 20052015. Extract from the final report of the World Conference on Disaster Reduction, Kobe, Hyogo, Japan.

United Nations. (2006). Global survey of early warning systems: An assessment of capacities, gaps and opportunities toward building a comprehensive global early warning system for all natural hazards. Geneva, Switzerland: UNISDR.

United Nations. (2015). Sendai framework for disaster risk reduction 2015-2030. Geneva, Switzerland: UNISDR.

United Nations. (2016). Report of the open-ended intergovernmental expert working group on indicators and terminology relating to disaster risk reduction. http://www.preventionweb.net/files/50683 oiewgreportenglish.pdf.

United Nations. (2017). Development Policy and Analysis DivisionDepartment of Economic and Social Affairs List of Least Developed Countries. https://www.un.org/development/desa/dpad/leastdeveloped-country-category/ldcs-at-a-glance.html.

Upreti, B. N., \& Dhital, M. R. (1996). Landslide Studies and Management in NepalRep., 87 pp., ICIMOD.

Vaidya, R. A., Sharma, E., Karky, B. S., Kotru, R., Mool, P., Mukherji, A., et al. (2014). Synthesis: Research insights on climate change and water resources management in the Hindu Kush Himalayas. In R. A. Vaidya 
\& E. Sharma (Eds.), Research insights on climate and water in the Hindu Kush Himalayas (pp. 1-38). Kathmandu, Nepal: ICIMOD.

Vatsa, K. S. (2002). Technological challenges of the disaster management plan for the state of Maharashtra. In S. Bhatnagar \& R. Schware (Eds.), Information and communication technology in development: Cases from India (pp. 50-62). New Delhi, India: Sage Publications.

Wang, S. Y., Yoon, J. H., Gillies, R. R., \& Cho, C. (2013). What caused the winter drought in Western Nepal during recent years? Journal of Climate, 26, 8241-8256.

Wang, S. Y., Fosu, B., Gillies, R. R., \& Singh, P. M. (2015). The deadly himalayan snowstorm of October 2014: Synoptic conditions and associated trends. Bulletin of the American Meteorological Society, 96, S89-S94.

Wasson, R. J., \& Newell, E. B. (2015). Links between floods and other water issues in the Himalayan and Tibetan Plateau Region. Pacific Affairs, 88(3), 653-676.

Wasson, R. J., Sundriyal, Y. P., Chaudhary, S., Jaiswal, M. K. Morthekai, P., Sati, S. P., et al. (2013). A 1000-year history of large floods in the Upper Ganga catchment, central Himalaya, India. Quaternary Science Reviews, 77(2013), 156-166.

Wesnousky, S. G., Kumahara, Y., Nakata, T., Chamlagain, D., \& Neupane, P. (2017) New observations disagree with previous interpretations of surface rupture Along the Himalayan frontal thrust during the great 1934 Bihar-Nepal earthquake. Geophysical Research Letters, 45(6), 2652-2658.

World Bank. (2005). Natural disaster hotspots: A global risk analysis. Disaster Risk Management Series No. 5. Washington, DC: The World Bank.

World Bank. (2013). Reducing poverty by closing South Asia's infrastructure gap. The World Bank and Australian Aid.

World Bank. (2017). Disaster risk profile: Afghanistan. Washington, DC: The World Bank.

World Economic Forum. (2014). Competitiveness Dataset. http:// www3.weforum.org/docs/GCR2014-15/GCI_Dataset_2006-072014-15.xlsx.

Yadav, R., \& Singh, J. (2002). Tree-ring-based spring temperature patterns over the past four centuries in Western Himalaya. Quaternary Research, 57, 299-305.

Yao, T., Thompson, L., Yang, W., Yu, W., Gao, Y., Guo, X., et al. (2012). Different glacier status with atmospheric circulations in Tibetan Plateau and surroundings. Nature Climate Change, 2(663667), 2012.

Ziegler, A. D., Wasson, R. J., Bhardwaj, A., Sundriyal, Y. P., Sati, S. P., Juyal, N., et al. (2014). Pilgrims, progress, and the political economy of disaster preparedness-The example of the 2013 Uttarakhand flood and Kedarnath disaster. Hydrological Processes. https://doi.org/10.1002/hyp.10349.
Open Access This chapter is licensed under the terms of the Creative Commons Attribution 4.0 International License (http:// creativecommons.org/licenses/by/4.0/), which permits use, sharing, adaptation, distribution and reproduction in any medium or format, as long as you give appropriate credit to the original author(s) and the source, provide a link to the Creative Commons license and indicate if changes were made.
The images or other third party material in this chapter are included in the chapter's Creative Commons license, unless indicated otherwise in a credit line to the material. If material is not included in the chapter's Creative Commons license and your intended use is not permitted by statutory regulation or exceeds the permitted use, you will need to obtain permission directly from the copyright holder. 